\title{
Experimental and Theoretical Investigations of Hard Rocks at High Temperature: Applications in Civil Engineering
}

\author{
Mambou Ngueyep Luc Leroy $\mathbb{D}^{1,2}$ Foguieng Wembe Marius, ${ }^{3}$ and Ngapgue François ${ }^{3,4}$ \\ ${ }^{1}$ Laboratory of Material Sciences, Department of Physics, Faculty of Science, University of Yaoundé 1, P.O. Box 812, Yaoundé, \\ Cameroon \\ ${ }^{2}$ Department of Mine Mineral Processing and Environment, School of Geology and Mining Engineering, \\ University of Ngaoundéré, P.O. Box 115, Meiganga, Ngaoundéré, Cameroon \\ ${ }^{3}$ Unité de Recherche de Mécanique et de Modélisation des Systèmes Physiques (UR-2MSP), Department of Physics, \\ Dschang School of Science and Technology, University of Dschang, P.O. Box 67, Dschang, Cameroon \\ ${ }^{4}$ Laboratory of Industrial and Systems Engineering Environment (LISIE), Department of Civil Engineering, \\ Fotso Victor Institute of Technology, Dschang School of Science and Technology, University of Dschang, Dschang, Cameroon
}

Correspondence should be addressed to Mambou Ngueyep Luc Leroy; mamboulucleroy@gmail.com

Received 30 May 2020; Revised 13 December 2020; Accepted 27 February 2021; Published 15 March 2021

Academic Editor: Xiaodong Hu

Copyright (c) 2021 Mambou Ngueyep Luc Leroy et al. This is an open access article distributed under the Creative Commons Attribution License, which permits unrestricted use, distribution, and reproduction in any medium, provided the original work is properly cited.

\begin{abstract}
This review paper aims to survey and discuss recent theoretical and experimental works reporting the temperature effects on the mechanical properties of rocks like granite, gabbro, gneiss, marble, sandstone, basalt, limestone, and argillite to permit the new challenge in this domain. The effect of high temperatures on various mechanical and physical material properties (Young's modulus, porosity, tensile and compressive strengths, P-wave velocity, permeability, thermal damage, and expansion) is analyzed. This work shows that hard rock mechanical and physical properties evolutions are strongly related to the evolution of the microstructure caused by the geological history, cracks nucleation occurrences, recrystallization, dehydroxylation, and dehydration reactions. However, it should be emphasized that these studies were not conducted on all types of intrusions and all rocks types. Meanwhile, it has been noticed that variations in temperature could lead to contradictory phenomena. Therefore, different trends were observed for the evolution of physical properties of rocks. There is an increase in porosity approximately $80 \%$ above $500^{\circ} \mathrm{C}$. In general, for volcanic's rock, the loss mass and thermal conductivity were drastically observed at low temperatures around $200^{\circ} \mathrm{C}$ with an antinomic phenomenon. Sandstone, granite, and argillite present the model whose behaviors with thermal load are too much explored accordingly with experiments compared with other rocks. Argillite at $200^{\circ} \mathrm{C}$ and sandstone and granite at $400^{\circ} \mathrm{C}$ undergo seriously damage. There is $100^{\circ} \mathrm{C}$ gap between the results obtained in real-time and those obtained after cooling. Moreover, $300^{\circ} \mathrm{C}$ can be considered as the critical temperature for real-time temperature heat treatment at which rocks lose almost about $80 \%$ of their performance. Otherwise, it is not easy to predict the behavior at high temperature of volcanic rocks like basalt and metamorphic rocks like gneiss which present the complexity in their behavior. For plutonic and metamorphic rocks, $600^{\circ} \mathrm{C}$ is the critical thermal load. At this temperature, the modulus of elasticity as well as the compressive strength of the most explored rock shows a significant decrease of about $75 \%$ for hard rocks. In sum, high temperature damages significantly the mechanical performance of rock. It is the reason for which these results may be useful to characterize the damage and thus predict the dramatic consequences of large temperature fluctuations on engineering structures in the rock.
\end{abstract}

\section{Introduction}

Centuries ago, human beings used wood to build their monuments and houses, but due to natural hazards such as fire, they started to use incombustible material like rock such as sandstone, granite, gabbro, gneiss, basalt, marble, concrete, and stabilized bricks [1]. Hard rocks are particularly geomaterials which have inhomogeneous, anisotropic, and nonlinear structures. The behavior of these rocks in thermal loading remains relevant. High temperature is an important 
factor in geotechnical engineering and its applications, especially in rocks, underground excavation for deep mining and caverns, geothermal energy resource exploration, underground nuclear fuel storage, underground coal gasification, and constructional projects such as pavements, exterior decorations, roads, and tunnels $[1,2]$. On the other hand, an increase in temperatures in public civil structures, buildings, and others due to fire leads to pay attention about its impact on the lifetime of these structures. However, in developing countries, such as Cameroon, the thermomechanical fragmentation practiced in different quarries and artisanal mines for many years deserves the examination of the influence of high temperatures on hard rocks such as granite, gneiss, basalt, marble, and sandstone generally found and exploited in these quarries. Owing to the industrial and artisanal applications of the subsequent products and regarding the nature of the rocks, this topic has always been of great interest to be explored. Aggregates widely used in the field of construction "Buildings and Public Works" represent $60-80 \%$ of the composition in volume of concrete. Thus, rocks were the most used materials in construction after water and air. The importance of this area in everyday life is well established and reflected the fact that the behavior of aggregates and concretes subjected to high temperature is still an issue of great importance that requires an in-depth scrutiny. At high temperature it is known that, the aggregates break down and undergo important physicochemical mineral changes, which essentially change the microstructural characteristics of the material [1-3]. Aggregates are generally composed of minerals optionally a matrix and include cracks, pores, and fluids inclusions. The geometry and density of these intergranular and intragranular cracks and pores are the key control parameters for their physical properties. For a better understanding of the mechanical behavior of rocks under mechanical and thermal stresses, several experimental studies were performed on different rocks in accordance with the ISRM (International Society for Rock Mechanics) suggested method which indicated that $L / D$ ratio is approximately 2 , where $L$ is the length and $D$ is a diameter of specimen. In agreement with this previous standard norm, the heating program used by many authors before to evaluate mechanical properties is presented as follows:

Room temperature $\stackrel{\text { heating rate }}{\longrightarrow} 100^{\circ} \mathrm{C}($ hold $1-2 \mathrm{~h}) \stackrel{\ldots}{\longrightarrow} \ldots$ final temperature $\stackrel{\text { forced/free cooling }}{\longrightarrow}$. However, few authors have evaluated these mechanical characteristics under real-time temperature.

These include the works of Houpert and Homand in 1989 [4] on Senones granite, Clarté granite, Euville limestone, Carrara marble, and Vosges sandstone. The heating rate used in their work was $50^{\circ} \mathrm{C} / \mathrm{h}$ up to $300^{\circ} \mathrm{C}$ and $100^{\circ} \mathrm{C} / \mathrm{h}$ above the same temperature with $L / D=2$. They investigated the mechanical properties of these rocks at various temperatures of $20^{\circ} \mathrm{C}, 200^{\circ} \mathrm{C}, 400^{\circ} \mathrm{C}, 500^{\circ} \mathrm{C}$, and $600^{\circ} \mathrm{C}$ assuming that by applying uniaxial compressive strengths, the effects of rock heterogeneities were negligible by confined applied pressure at high temperature. At the end of their work, they concluded that, for crystalline rocks, the decrease in mechanical properties was monotone. Furthermore, the residual compressive strength at low temperature is significantly different from that measured at high temperature. Therefore, the value of $500^{\circ} \mathrm{C}$ is the critical temperature when considering low strain rates.

In 2007, Rao et al. [5] studied the mechanical properties of sandstones under real-time temperature of $20^{\circ} \mathrm{C}, 60^{\circ} \mathrm{C}$, $100^{\circ} \mathrm{C}, 150^{\circ} \mathrm{C}, 200^{\circ} \mathrm{C}, 250^{\circ} \mathrm{C}$, and $300^{\circ} \mathrm{C}$ with the heating rate of $30^{\circ} \mathrm{C} / \mathrm{min}$. Rao et al. showed that below $250^{\circ} \mathrm{C}$, the uniaxial compressive and tensile strength as well as Young's modulus and mode I fracture toughness increase linearly with temperature. Above $250^{\circ} \mathrm{C}$, these mechanical parameters change in the opposite direction. They concluded that the mineralogical composition of rocks has a major influence on its mechanical properties at this range of temperature.

In 2009, Zhang et al. [6] on marble, limestone, and sandstone used MTS810 Rock Mechanics Servo-Controlled Testing System to appreciate the behavior of their mechanical properties (compressive strength, strain, and Young's modulus) under real-time temperature ranging from $20^{\circ} \mathrm{C}$ to $800^{\circ} \mathrm{C}$ with the heating rate of $2^{\circ} \mathrm{C} / \mathrm{s}$ and $L / D$ ratio of 2.25. The authors observed that $\left(\sigma_{c}\right)_{\text {Sandstone }}>\left(\sigma_{c}\right)_{\text {Limestone }}>\left(\sigma_{c}\right)_{\text {Marble }}$ with the decrease of about $70 \%$ of compressive strength $\sigma_{c}$ of limestones at $800^{\circ} \mathrm{C}$. This equation remains valid in the case of strains. From the critical temperature of $600^{\circ} \mathrm{C}$, Young's modulus decreases of about $80 \%$ for sandstones and 35\% for limestones. However, above $200^{\circ} \mathrm{C}$, marble and sandstones undergo strains that increase by about $150 \%$. In the same year, Mao et al. [7] showed under real-time that Young's modulus of limestones decreases by about $80 \%$ when temperatures increase from $600^{\circ} \mathrm{C}$ to $800^{\circ} \mathrm{C}$ with the heating rate of $2^{\circ} \mathrm{C} / \mathrm{s}$ and $L / D=2.25$. However, the value of $600^{\circ} \mathrm{C}$ is the temperature at which plastic strain was initiated.

In 2010, Keshavarz et al. [8] evaluated the impact of temperature ranging from $25^{\circ} \mathrm{C}$ to $1000^{\circ} \mathrm{C}$ on the mechanical properties of gabbro with the heating rate of $100^{\circ} \mathrm{C} / \mathrm{h}$ and $L / D=2.25$. Keshavarz et al. noted that after thermal treatment, $600^{\circ} \mathrm{C}$ is the critical temperature at which this rock shows serious damage due to a significant decrease in its Young's modulus and its compressive strength. In this rock, oxidation of $\mathrm{Fe}^{2+}$ and $\mathrm{Mg}^{2+}$ ions in fluids inclusion results in a modification of the rock structure with the development of microcracks by an inequitable thermal expansion in the mineral compositon of the rocks.

In 2012, Saiang and Miskovsky [9] analyzed the mechanical behavior of granite, schists, and diabase at room temperature and temperature levels of $450^{\circ} \mathrm{C}, 750^{\circ} \mathrm{C}$, and $1100^{\circ} \mathrm{C}$ with an average heating rate of $0.8^{\circ} \mathrm{C} / \mathrm{min}$ to $1.5^{\circ} \mathrm{C} /$ min. After heat treatment, they concluded that mechanical properties such as Young's modulus and compressive and tensile strengths decrease almost linearly as temperature and the width of microcracks increase.

Other works such as those of Ranjith et al. [10] on Hawkesbury sandstone in 2012 performed the compressive strength test and measured Young's modulus on heated rock specimens under real-time to temperature ranging from $25^{\circ} \mathrm{C}$ to $950^{\circ} \mathrm{C}$ with the heating rate of $5^{\circ} \mathrm{C} / \mathrm{min}$ and $L / D=2$. They reported that the critical temperature value is $500^{\circ} \mathrm{C}$. Their X-ray diffraction analysis showed the dehydroxylation of kaolinite above $500^{\circ} \mathrm{C}$, thus reducing uniaxial compressive 
strength. The authors of [10] demonstrated in their results that the modified microstructure affects the mechanical properties of rocks.

In 2013, Wu et al. [11] using Jiaozuo sandstone explored the mechanical properties after they subjected the rocks to temperature ranging from $20^{\circ} \mathrm{C}$ to $1200^{\circ} \mathrm{C}$ with the heating rate of $5^{\circ} \mathrm{C} / \mathrm{min}$ and $L / D=2$. The authors reported that rocks change their physical appearance from a dark to light color. Furthermore, after heat treatment, these rocks contracted below $400^{\circ} \mathrm{C}$ whereas a significant change in density was observed above $800^{\circ} \mathrm{C}$. The elasticity modulus decreased rapidly at $400^{\circ} \mathrm{C}$ while the dynamic Poisson coefficient increased significantly above $800^{\circ} \mathrm{C}$. They concluded that these rocks presented a plastic behavior at high temperature as in $[7,10]$.

In 2015, Hartlieb et al. [12] investigated on the thermophysical properties of granite, sandstones, and basalt rocks from room temperature to high temperature of about $1000^{\circ} \mathrm{C}$. Their works showed that the allotropic transition from $\alpha$ quartz to $\beta$ quartz influenced the physical properties of the specimen while above $870^{\circ} \mathrm{C}$, tridymite phase was appeared. They also used nondestructive tests with an irradiation power of $17.5 \mathrm{~kW}$ and concluded that the mineralogical structure has a major influence on the modification of the physical parameters and stability of the rock. In the same year, Yu et al. [13] on red sandstone studied its mechanical properties and permeability evolution at $20^{\circ} \mathrm{C}, 200^{\circ} \mathrm{C}, 400^{\circ} \mathrm{C}$, and $600^{\circ} \mathrm{C}$ with the heating rate of $10^{\circ} \mathrm{C} / \mathrm{min}$ and $L / D=2$. After thermal treatment, Yu et al. recorded an increase in strength and Young modulus with a decrease in permeability due to internal cracks and pores closure below $200^{\circ} \mathrm{C}$. From $200^{\circ} \mathrm{C}$ to $600^{\circ} \mathrm{C}$, they observed that the Young modulus and strength decreased significantly. Otherwise, permeability increased also seriously with the evolution of the cracks.

In 2016, Gautam et al. $[14,15]$ analyzed the mechanical properties of Dholpur sandstone subjected to high temperatures up to $950^{\circ} \mathrm{C}$ with the heating rate of $2^{\circ} \mathrm{C} / \mathrm{s}$ and $L / D$ ratio equals 2.46. At the end of their work, they realized that after heat treatment below $450^{\circ} \mathrm{C}$, its elasticity modulus increased. However, above $650^{\circ} \mathrm{C}$ (considered as critical temperature), this modulus decreased by about $78.37 \%$. Furthermore, from $800^{\circ} \mathrm{C}$, the compressive strength of rocks decreases by about $45.84 \%$. Finally, they proposed a linear relationship characterizing the thermal damage $D(T)$ of the rock specimen as a function of the maximum stress applied $\sigma_{p}$ and the induced strain $\varepsilon_{f}$ in the form of the following equation:

$$
D(T)=1.6 e^{-4}+1.72 e^{-2} \sigma_{p}+4.89 e^{3} \varepsilon_{f} .
$$

Their correlation coefficient was approximately 0.876 which confirmed its applicability reported in [15]. It means that mineral composition of rock submitted at heat treatment was modified.

In 2017, Lintao et al. [16] on sandstone studied rock samples in temperature range from $20^{\circ} \mathrm{C}$ to $1000^{\circ} \mathrm{C}$ with the heating rate of $5^{\circ} \mathrm{C} / \mathrm{min}$ and $L / D=2$. They studied the physical and chemical properties of their specimens through
TGA and TDA as well as X-ray diffraction, mechanical triaxial tests, and nondestructive tests including microtomography after thermal treatment. Their works showed that below $400^{\circ} \mathrm{C}$, there is dehydration and growth in the mechanical properties. Between $400^{\circ} \mathrm{C}$ and $800^{\circ} \mathrm{C}$, due to the thermal expansion, microcracks were created therefore increasing porosity while the mechanical properties of rocks were decreased. Above $800^{\circ} \mathrm{C}$, the mineralogical composition of the rock is greatly modified with the emergence of microcracks within minerals leading to a significant reduction in mechanical properties.

Keppert et al. [1] in 2017 also contributed to a deeper understanding of the mechanical behavior of a sandstone hard rock containing clay, quartz, and calcite under high temperature range from $25^{\circ} \mathrm{C}$ to $900^{\circ} \mathrm{C}$ with the heating rate of $10^{\circ} \mathrm{C} / \mathrm{min}$. From the compressive strength and microstructural analyses, they demonstrated after heat treatment that the mineralogical composition and diagenesis of rock have a great influence on the increase or decrease in its mechanical properties.

Several literature research studies also underlined the creation of microcracks by heating rate ranged between $5^{\circ} \mathrm{C} /$ min and $50^{\circ} \mathrm{C} / \mathrm{min}$ and concluded that it plays a significant role in the mechanical properties of the rocks [17-19]. As this velocity increased, the chemical structure was modified and the stiffness of rock increased.

In 2017, Diaz [2] reported an experimental study review on the temperature effect in altering the rigid mechanical properties of materials like granite, clay, basalt, argillite, and glass. This review presented an acceptable range of temperature of the materials so as to avoid cracking and breaking of the materials during engineering applications.

In 2018, Zhiliang et al. [20] analyzed the mechanical behavior of granite subjected to thermal loading of $20^{\circ} \mathrm{C}$, $200^{\circ} \mathrm{C}, 400^{\circ} \mathrm{C}$, and $600^{\circ} \mathrm{C}$ then to cyclic mechanical loading. They observed an initial damage of -0.11 from $200^{\circ} \mathrm{C}$ and at $600^{\circ} \mathrm{C}$, and it is 0.58 . Zhiliang et al. concluded that high temperature leads to a change in the microscopic structure of rocks and very pronounced degradation of its mechanical properties. In the same year, Rathnaweera et al. [21] reported similar conclusion on clay-rich Hawkesbury sandstone under high temperature range from $25^{\circ} \mathrm{C}$ to $1000^{\circ} \mathrm{C}$. Otherwise, Gautam et al. [22] proved that after heat treatment above $300^{\circ} \mathrm{C}$, Jalore granite rocks damaged significantly affecting the thermal conductivity and P-wave velocity seriously. The authors of [22] concluded that this physicomechanical degradation will be useful for designing safe rock structures to prevent the damage of nuclear waste deposits and heat mining in enhanced geothermal energy. Gautam et al. [23] observed the plasticity behavior of granite specimen after thermal treatment in the range of $300-600^{\circ} \mathrm{C}$ with a slow heating rate of $10^{\circ} \mathrm{C} / \mathrm{min}$ and $L / D=2.40$. The authors of [23] showed that also the complexity of thermal expansion and densification level are responsible to crack density and proved that there is a very strong relation between compressive strength and Young's modulus.

In 2019, Wu et al. [24] presented their results on Shandong granite samples heated between $25^{\circ} \mathrm{C}$ and $600^{\circ} \mathrm{C}$ to evaluate the behavior of their physical and mechanical 
properties. The heating rate used here was $5^{\circ} \mathrm{C} / \mathrm{min}$ and $\mathrm{L} /$ $D=2.04$. The authors demonstrated that using nitrogen for the sudden cooling of a heated material induced its significant damage, unlike using water or air. Physical properties are therefore severely altered. They also proved that when using electron microscopy, microcracks were first formed around the quartz grains before propagating throughout the entire rock, causing a decrease in its rigidity.

Peng and Feng [25] in 2019 also showed that thermal expansion decreased with a large number of heat cycles. The granite samples have been heated under high temperature up to $600^{\circ} \mathrm{C}$, and the heating rate was between $2^{\circ} \mathrm{C} / \mathrm{min}$ at $5^{\circ} \mathrm{C} / \mathrm{min}$ and $L / D=2$. However, moving from a triaxial compression test to uniaxial compression test for a fixed cycle number after heat treatment, the extension of strain is very large and the thermal expansion coefficient is higher. It is similar when the heating rate is high [25]. In the same year, Soprani et al. [26] investigated a combination of bottom steam cycles with high temperature thermal energy storage systems as potential cost-effective alternatives to traditional large-scale energy storage technologies. After thermal treatment, they demonstrated using different rock bed configurations that a storage capacity of $450 \mathrm{kWh}$ enabled to have $600^{\circ} \mathrm{C}$ at certain positions [2]. However, their results showed that in charge and discharge cycles, the efficiency of the best configurations was about $68 \%$. Healy et al. [27] demonstrated that minerals were intrinsically anisotropic, thus can become elastic and affect the rock structure, consequently the physical and mechanical properties of these rocks. At the same time, Gautam et al. [28] revealed using microscopic analysis that feldspar minerals have a low and isotropic thermal expansion which do not affect the molecular structure of red and white Jalore granitic rocks for nuclear waste repository. However, there is a good exponential growth relation between thermal strain and temperature. The heating rate used was $5^{\circ} \mathrm{C} / \mathrm{min}$ and cooling rate $0.36^{\circ} \mathrm{C} / \mathrm{min}$, and then $L / D$ ratio equals 2 and disc specimens have dimension of $31 \mathrm{~mm}$ in thickness and $54 \mathrm{~mm}$ in diameter [28].

Recently in 2020, Rivas et al. [29] proved with the contribution of the 21st International Conference on deformation mechanisms in the University of Aberdeen that the competition between viscoplastic strain and dynamic recrystallization in molten rocks is around the mineral grain. Their results showed that there exist the techniques and development of new ones to compelling advances in our understanding of strain processes. The authors of [29] noted that mechanical anisotropy is an important factor which controls strains in structures. Wong et al. [30] showed that for important underground engineering projects, there is a transition time at high temperature at which rock has been from strengthening to weakening. However, up to $200^{\circ} \mathrm{C}$, using intrinsic rock properties, its strength is increased [30].

Finally, these works reveal many gaps and contradictions on the evolution of these properties as a function of temperature. For instance, some authors indirectly consider $400^{\circ} \mathrm{C}$ as the critical temperature, while others $[4,10]$ reported $500^{\circ} \mathrm{C}$ as critical temperature, as well as $600^{\circ} \mathrm{C}$
$[6-8,13,15,21,26]$ and $800^{\circ} \mathrm{C}[11,16]$. However, some authors $[4,6,8,10,13,15]$ used destructive methods (compressive and tensile strengths) and others $[12,16]$ used nondestructive methods such as gas permeability, $\mathrm{P}$-wave velocity, and attenuation. These methods have been doing when their rock specimens are cooled and contribute to have generally the same response. In other case, few works have presented mechanical parameters when rock specimens were submitted simultaneously at thermal treatment and mechanical or physical tests.

Considering these previous cited rocks, it is noted that many authors have specified different point of view specifically in macroscopic or microscopic behavior, heat transfer, fluids intrusions, and microcracks. We have noted that, in general, it is almost unanimously clear that high temperature reduced significantly the mechanical properties of hard rock.

In spite of the fact that each rock has its mineral composition and diagenesis, it is difficult to generalize the behavior of rocks at high temperature. Consequently, a review paper which summarized the behavior of several rocks is necessary to enrich scientific community and give the new challenge in rock mechanics. Indeed, the best knowledge of the behavior of rock at high temperature still remains one challenge in the domain considering used tests in situ or in the laboratory, the geological context, the anisotropy of thermal expansion of mineral grains, the heating and cooling rates, the velocity of measurement of one choosed physical, or mechanical parameter.

In this work, we reviewed both experimental and theoretical research studies on the effect of temperature on mechanical residual or instantaneous properties of rocks such as granite, gabbro, gneiss, marble, sandstone, basalt, limestone, and argillite. Section 1 is devoted to general introduction. In Section 2, the physicochemical changes of rocks at high temperature will be presented, whereas in Section 3, the influence of temperature on mineralogical composition will be reported. In Section 4, the influence of high temperature on the microstructure of hard rocks will be exposed in Section 4. In Section 5 , the high temperature effect on the physical properties of rocks will be discussed. Then, in Section 6, the thermal damage, the theory, and cool and heat tests comparison will be reviewed, respectively. Our own experimental and theoretical works will be presented below.

\section{Physicochemical Changes of Rocks at High Temperature}

2.1. Thermal Reaction. Hard rocks are composed of many minerals, mainly silicates. The most important silicates are feldspars, quartz, olivine, pyroxene, amphibole, garnet, and mica. When these rocks were subjected to heat, the mineral contents undergo different reactions as summarized in Table 1.

For clay minerals, desorption reactions evacuated water absorbed between the layers and in the structural channels while the decomposition reactions converted the bound water in hydroxide ion. Thermal decomposition of calcite begins at $700^{\circ} \mathrm{C}$ under high heating rates reported in [32]. 
TABle 1: Thermal reactions in rocks [31].

\begin{tabular}{lccccc}
\hline Temperature $\left({ }^{\circ} \mathrm{C}\right)$ & $25-200$ & $400-700$ & 573 & $700-830$ & $790-900$ \\
\hline Minerals & Clay mineral & Clay mineral & Quartz & Calcite & Clay mineral \\
Reactions & Desorption & Decomposition & $\alpha-\beta$ transition & Decomposition & Decomposition \\
\hline
\end{tabular}

These reactions play a major role in mass loss and can damage the structure of the rocks during heating. Dawe et al. [32] showed that at high temperatures and high heating/ cooling rates $\left(30^{\circ} \mathrm{C} / \mathrm{min}-50^{\circ} \mathrm{C} / \mathrm{min}\right), \mathrm{CaCO}_{3}$ occurred by reducing the fraction of anorthite in the material. On the other hand, Ming et al. [17] revealed that when heating rate increased from $5^{\circ} \mathrm{C} / \mathrm{min}$ to $50^{\circ} \mathrm{C} / \mathrm{min}$, both the longitudinal wave velocity and the density decreased contributing to a decrease in the microscopic energy consumption, thus causing a macroscopic damage of the sandstone rock. Later, for lower heating/cooling rates from $0.17^{\circ} \mathrm{C} / \mathrm{s}$ to $20^{\circ} \mathrm{C} / \mathrm{s}$ applied on granite and sandstone, Rossi et al. [33] assumed that the rigidity of the rock was reduced by about $30 \%$ with the presence of cracks in rocks.

2.2. Oxidation Reaction. Oxidation and phase transformation are other phenomena that take place in rocks crystallization during thermal treatment. The oxidation of iron and magnesium species enriched compounds occurred at ambient pressure. The results of microscopic analysis by Keshavarz et al. [8] confirmed an oxidation phenomenon in samples of gabbro processed at high temperature. This oxidation of minerals begins at temperature around $500^{\circ} \mathrm{C}$. For rocks with no quartz as gabbro of North Africa, they found that the oxidation of $\mathrm{Fe}, \mathrm{Mg}$, and $\mathrm{Ti}$ containing crystals plays a major role in changing its mechanical and physical parameters [8]. According to microscopic observations made by Chen and Dollimore [34], oxidation is a transitional phase in this type of rock. We can conclude that at high temperature, physicochemical changes with thermal and oxidation reactions played a vital role in rock structure which induced the major impact in mechanical parameters.

\section{Influence of Temperature on Mineralogical Composition}

Based on the work of [35-37], some mineralogical changes may occur in rocks under high temperature. These changes resulted in the induced physical properties [11]. This section described the transformation of minerals, especially the most commonly encountered in aggregates for concrete.

(1) The stable form of silica at low temperature is $\alpha$ quartz. Above $573^{\circ} \mathrm{C}$, at ambient pressure, a slight rotation of the bonds between tetrahedral leads to a crystalline form of hexagonal symmetry; the formation of $\beta$ quartz was accompanied by $2 \%$ in volume expansion [1]. This transformation was made by crystallographic similarity of these two varieties of quartz [38] and was perfectly reversible in the phase where specimen is cooled down to room temperature. Bazant and Kaplan [39] and Toifl et al. [40] noted that this abrupt phase changes from state $\alpha$ to state $\beta$ were accompanied by a change in volume from 1 to $5.7 \%$. Some authors reported that this expansion in volume can reach up to $8 \%[11,41-43]$. The volumetric change resulted in a damaging effect on concretes manufactured with such materials when exposed to high temperature. The temperature of the $\alpha-\beta$ transition of quartz can also increase with pressure.

(2) Zhiliang et al. [20] showed that feldspars minerals have no structural alteration until $700^{\circ} \mathrm{C}$.

(3) Micas were aluminosilicates with various colors according to the chemical composition. Included among other muscovite which according to the variety undergoes changes from $750^{\circ} \mathrm{C}$ to $900^{\circ} \mathrm{C}$. Biotite (or mica black) which is a solid solution does not undergo dehydroxylation in the range of relevant temperatures when healthy [25, 43-45].

(4) Calcite after quartz is the most common mineral in the surface of earth. Calcite begins to dissociate (decarbonisation) in a ventilated oven from $660^{\circ} \mathrm{C}$ [44].

(5) Menou et al. [44] found that limestone aggregates have good thermal performance up to $700^{\circ} \mathrm{C}$. Beyond this temperature, calcium carbonate begins to decompose to calcium monoxide $(\mathrm{CaO})$ called lime. This reaction removed a considerable amount of $\mathrm{CO}_{2}$, which peaked at about $800^{\circ} \mathrm{C}$. At $898^{\circ} \mathrm{C}$, the author of [43] showed that the decarbonisation was completed and caused a breakdown of the aggregates.

(6) Clay minerals and phyllo silicate were more sensitive to heat and showed severe transformations at high temperature [46]. In this category of minerals, we found the alteration of silicates minerals (feldspars, for example) such as kaolinite, sericite, and illite.

(7) The structure of kaolinite disappeared completely around $550^{\circ} \mathrm{C}$. Above $1100^{\circ} \mathrm{C}$, kaolinite undergoes dehydroxylation reactions to form mullite $[43,47-49]$ which is a metastable form of kaolin presented in amorphous form.

(8) The illite was more stable than kaolinite and still persists at $900^{\circ} \mathrm{C}$ despite having lost its entire water constituent (dehydroxylation/dehydration) at $553^{\circ} \mathrm{C}$. Clay minerals generally lose some water (adsorption) around $105^{\circ} \mathrm{C}$. Dehydroxylation reactions produced around $410^{\circ} \mathrm{C}$ for illite, $430^{\circ} \mathrm{C}$ for kaolinite, and $700^{\circ} \mathrm{C}$ for sericite $[17,43]$. [48] showed that these mechanisms have a link between activation energy and defectivity of the reacting kaolinite. This phenomenon implies the beginning 
of nucleation around the mineral grain. Beside mineralogical changes, a change in color of the heated rock may also appear, indicating a conversion of clay minerals.

(9) Chlorites often result from the alteration of biotite. It is a mineral that can lose a bit of water adsorbed at $130^{\circ} \mathrm{C}$. Homand-Etienne [35] revealed that dehydroxylation reactions started at $450^{\circ} \mathrm{C}$ and continued up to $900^{\circ} \mathrm{C}$ depending on the variety.

(10) Goethite or jarosite is a form of oxi-hydroxyde iron $\mathrm{FeO}(\mathrm{OH})$. It is the only mineral which shows an alteration at high temperature. Its minimum temperature for dehydration to occur is $250^{\circ} \mathrm{C}$, with a water loss of about $11 \%$ [43]. This dehydration reaction leads to the formation of a new phase of mineral called hematite $\left(\mathrm{Fe}_{2} \mathrm{O}_{3}\right)$ at temperature of $900^{\circ} \mathrm{C}[36,37]$.

At the end of this section, we can conclude that the mineralogical composition implies finally an important modification in rock structure. Consequently, the anisotropy of thermal expansion of different minerals is reduced significantly with change in volume of rock specimen and impacted their mechanical parameters.

\section{Influence of High Temperature on the Microstructure of Hard Rocks}

Under the effect of temperature, the crystal lattice of the mineral and the structure of hard rocks changed with discontinuities such as microcracks and micropores [50, 51]. Even a very little heating of the rock (temperature from $50^{\circ} \mathrm{C}$ ) may induce microcracks in the microstructure of the rock [52-55]. Indeed, an increase in temperature produced a differential change in dimensions of the granulation of the rock, leading to microcracking $[17,56,57]$. This development of microcracks weakened the rock and therefore compromised its durability. By a statistical analysis, these microcracks were quantifiable $[58,59]$ and their geometries were also estimated. At the same time, the results obtained by SEM on granite [23, 36] showed that the density of intracrystalline microcracks increased excessively between $600^{\circ} \mathrm{C}$ and $850^{\circ} \mathrm{C}$. Furthermore, an increase in intracrystalline microcracks above $800^{\circ} \mathrm{C}$ also favored the creation of intercrystalline microcracks below $800^{\circ} \mathrm{C}$ [37, 60-62]. Fortin et al. [63] and Heard and Page [64] studied the evolution of microcracking within and around minerals with low porosity in Westerly granite subjected to temperature ranging from room temperature to $850^{\circ} \mathrm{C}$. Their work showed that an increase in temperature implies a decrease in the maximum applied stress during triaxial tests.

Darot et al. [63] showed that on an Iceland basalt, from $500^{\circ} \mathrm{C}$, there is a great increase in the thermal cracking of mineral grains. These induced microcracks randomly with the fall of the P-wave velocity from $5400 \mathrm{~m} / \mathrm{s}$ to $3100 \mathrm{~m} / \mathrm{s}$ unlike pores of basalt which are oriented in a parallel manner caused by the magmatic flow lava confirmed by the model of $[65,66]$. Fortin et al. [67] proved that wave velocities are very sensitive to basalt pores having a spherical geometry. Zhang et al. [68] showed that the heated sandstones undergo large structural modifications which lead to a major decrease in the $\mathrm{P}$-wave velocity, porosity, and moreover the increase in the damage to $600^{\circ} \mathrm{C}$. The increase in micropores weakened the compressive strength in the case of basalts [69]. Similarly, other works on different granites, basalts, and gabbros [8] have similar conclusions. Houpert and Homand [4] and Heuze [38] showed from the heat treatment of the Remiremont and Senones granites that the length of cracks does not increase significantly contrary to their width and their number which increase rapidly. Consequently, intergranular and intragranular microcracks are related to the differential expansion of the minerals leading to a growth in the permeability of these granites because these cracks have been generated, expanded, and connected.

Van den Kerkhof et al. [3] used X-ray diffraction with thermal analyses to investigate the changes in the chemical and physical properties of sandstone samples under high temperature. The results proved that the microstructure of sandstone was significantly modified and decreased their mechanical properties $[3,21]$. Similarly, from ambient temperature to $900^{\circ} \mathrm{C}$, the author of [70] analyzed the mechanical and physical properties of sandstone. In Figure 1, quartz and feldspar minerals have undergone serious modification in peak intensity. Feldspar mineral peak intensity decreased while quartz mineral intensity increased with increasing in temperature. Based on this $\mathrm{X}$-ray diffraction results, they concluded that from $400^{\circ} \mathrm{C}$ to $800^{\circ} \mathrm{C}$, porosity and many microcracks increase rapidly. However, the authors recorded that the critical temperature that gives profound changes in the mechanical behavior and permeability of sandstone is between $400^{\circ} \mathrm{C}$ and $500^{\circ} \mathrm{C}$. Shen et al. [71] used DRX, SEM, and ATG to characterize the changes of the microstructure of sandstones subjected to thermal stress. They confirmed the results presented in [31] by using ATG which indicated the mineral composition of the rock structure undergoing thermal reactions. Furthermore, pictures obtained from the SEM indicate $600^{\circ} \mathrm{C}$ as the critical temperature at which transgranular cracks appear.

We can conclude that the microstructure change tests are confirmed that the durability of hard rock is compromised with different phenomena which are produced by quartz and feldspar minerals than others.

\section{Influence of High Temperature on the Physical Property of Rocks}

Lion [70] and Wang et al. [74] showed that high temperature could lead to contradictory phenomena such as cracks and densification in hard rock, which can significantly influence their physical properties.

\subsection{Porosity and Permeability Evolution Depending on the} Temperature. Porosity is one of the basic physical properties of rocks. After heating, changes taking place on the porosity were generally related to thermal expansion, modification of microcracks network, and damage of rock structure. Total porosity was determined by using the triple weighing 


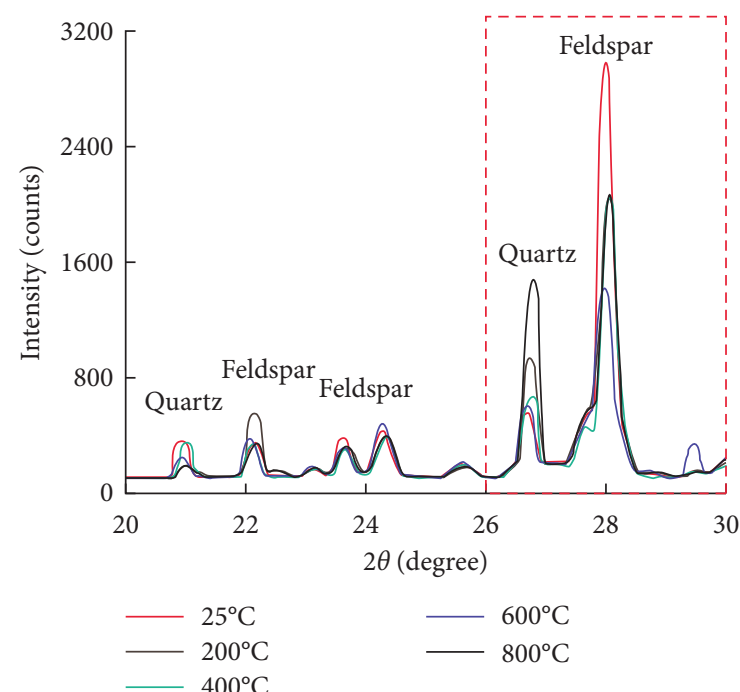

(a)

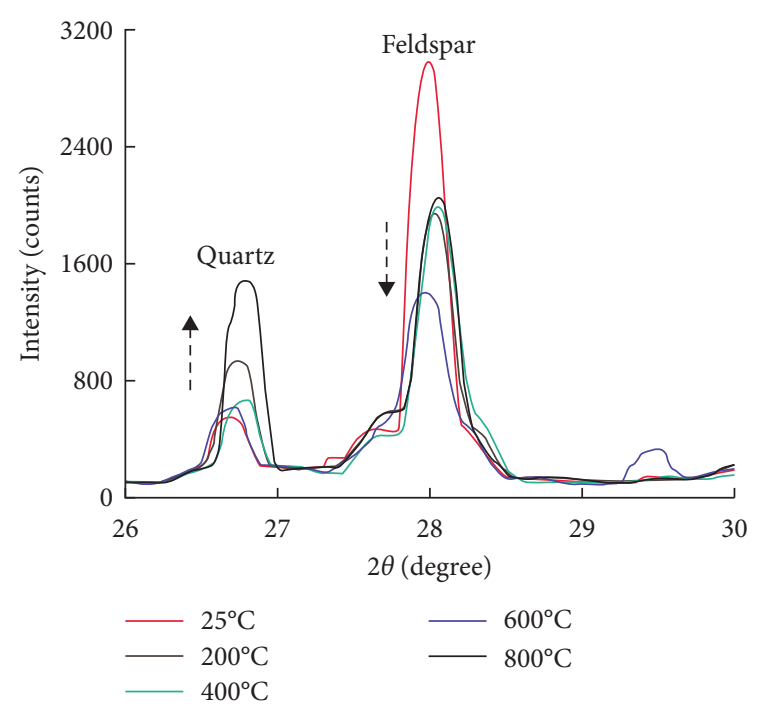

(b)

FIGURE 1: X-ray diffraction spectra for the powder of sandstone under various heat treatment temperatures [72, 73] (a) between the 2 $\theta$ angles of $20^{\circ}$ and $30^{\circ}$ and (b) between the $2 \theta$ angles of $26^{\circ}$ and $30^{\circ}$.

method as recommended by ISRM Norm [75]. It was often used even if it does not provide access to information on the heterogeneity of the porosity at a microscopic scale and fairly simple to make. It was technically measured by immersion in which the weighing of dry, saturation, and immerged sample was successively performed. The fluid used is water as in standard ISRM Norm. The method used Archimedes principle and gave accurate results.

Figure 2(a) represents the total porosity versus the temperature evolution. This figure showed an increase in porosity below $300^{\circ} \mathrm{C}$, resulting to the creation of new cracks and the opening of pre-existing cracks and pores. In general, it was reported that for all porosities, there was an abrupt increase at around $500^{\circ} \mathrm{C}$ in accordance with [32]. This growth increased significantly with the evolution of temperature due to the multiplication of microcracks in the rock structure which causes the structure of rock damage.

Permeability is one of the most important properties used to characterize porous materials. It enabled us to evaluate the transportation of rock properties [76-79]. It depends on the connectivity of the pores, their geometry, and shape. Figure 2(b) presents the permeability of granite which increased sharply around $500^{\circ} \mathrm{C}$. This observation was in accordance with the evolution of total porosity at this temperature [80-85].

Weak growth in porosity and permeability was observed in temperature ranging between $100^{\circ} \mathrm{C}$ and $400^{\circ} \mathrm{C}$. This showed that the sample undergoes a minor structural modification in this temperature range, resulting to an enlargement of the existing microcracks and certainly to a creation of new ones that expand depending on the temperature. The biggest change that occurred between $400^{\circ} \mathrm{C}$ and $600^{\circ} \mathrm{C}$ was induced by a significant growth of the opened microcracks and therefore increased porosity. In the case of sedimentary rocks, sandstone with high initial porosity in particular, Tian et al. [84] showed that from $600^{\circ} \mathrm{C}$, intergranular cracking increased rapidly. Similarly, considering carbonate rocks, micrite has a low cracking rate at $100^{\circ} \mathrm{C}$ compared with marble [58] which undergoes very high cracking rates. Sun et al. [82] used the pressure gradient from Darcy's law to experimentally determine the permeability of the heat-treated material in accordance with ISRM Norm. In their work, it appeared that using a containment pressure between $10 \mathrm{MPa}$ and $30 \mathrm{MPa}$, equivalent permeability $\left(K_{0}=A \times 1.01^{T}\right)$ decreased by about $91.06 \%$, previously predicted with a critical temperature of $T=400^{\circ} \mathrm{C}$.

\subsection{Evolution of the Normalized Elastic Wave Velocity as} Function of Temperature. Determining the velocity of propagation of elastic waves (acoustic waves) through the material before and after heating is an effective tool for assessing changes in its properties depending on the temperature. The results of a large number of researchers have shown that the propagation velocity of these waves in rocks depends on the mineral composition, density, porosity, microcracks, temperature, and especially the applied pressure $[19,42,59,86,87]$.

Houpert and Homand [88] showed that the velocity of longitudinal waves decreased when temperature increased. The decrease was attributed to the creation of new cracks or expansion of existing ones in the material [51, 89].

The intergranular stresses can lead to the cracking of the rock, especially at the joints of different grains [51]. These phenomena lead to both longitudinal and transversal significant reduction in wave velocities as confirmed by Figure 3. In this figure, normalized P-wave velocity of sedimentary rocks as claystone increase with temperature compared with other sedimentary rocks (sandstone), volcanic rocks (basalt), plutonic rocks (granite, gabbro), and metamorphic rocks (marble), in which normalized P-wave velocities decrease in general with increase in temperature 


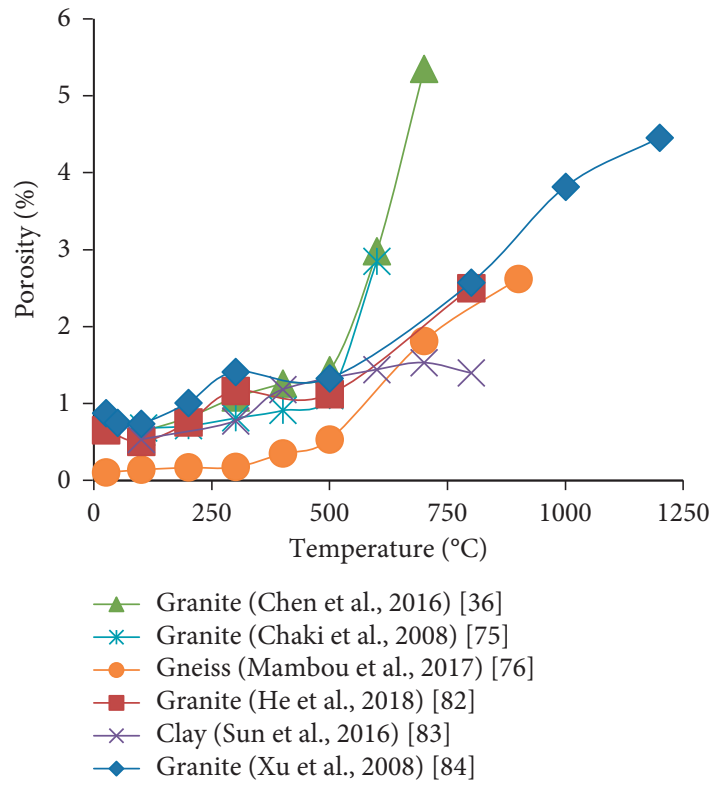

(a)

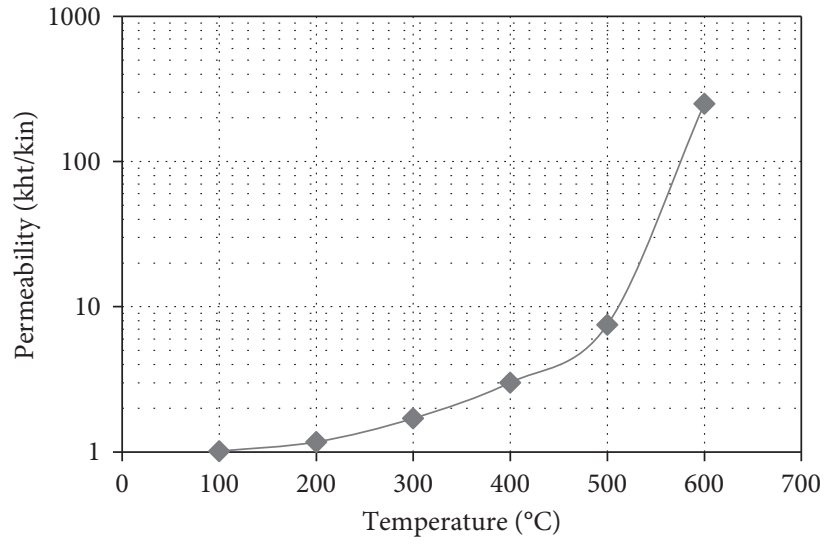

(b)

Figure 2: (a) Porosity of gneiss, granite, and clay with temperature. (b) Permeability of granite depending on temperature [75].

[90, 91]. In this case, we conclude that normalized P-wave velocity was not uniform for all rocks. We can consider $300^{\circ} \mathrm{C}$ as critical temperature at which normalized P-wave velocities of all of hard rocks decrease.

Takarli et al. [53] used a method of electrotransmission, to measure the P-wave velocity in a healthy sample of granite and a granite sample microfractured after heat treatment. They observed an identical behavior for both types of samples. The velocity decreased gradually and almost linearly up to $500^{\circ} \mathrm{C}$, at which a loss of about $32 \%$ was observed compared with the initial state $\left(105^{\circ} \mathrm{C}\right)$. Beyond this temperature, the velocity decreased more significantly and was around $63 \%$ at $600^{\circ} \mathrm{C}$. The reduction in velocity clearly indicated that the heat treatment induced irreversible changes that alter the path traveled by the wave.

\subsection{Evolution of Density as a Function of Temperature.} Heat treatment leads to the loss in mass and increased volume of rocks, which is a remarkable change in the density. According to the mineralogical nature of the rock, this mass loss can be varied as shown in Figure 4(a). The limestone aggregates that result from decarbonation of calcite and loss of $\mathrm{CO}_{2}$ undergo a greater mass loss. Then, the decrease in density also with thermal load is not more than $10 \%$. The works of [11] on sandstone confirms this phenomenon of mass loss when the materials are subjected to high temperature (Figure 4(b)). Indeed, we concluded that during the heating of a rock, its mass was subjected to variation due to the evaporation of water and progressive dehydration which contribute to enhance rock up to $350^{\circ} \mathrm{C}$ or to decrease its mechanical properties above $600^{\circ} \mathrm{C}$.

\subsection{Evolution of the Volume Depending on Temperature.} Generally, the rock subjected to high temperature increased in volume due to thermal expansion. The work of Tian et al.
[84], Tian et al. [89], and those of Somerton [31] showed that this change in volume was characterized by permanent elongation after cooling and returning to room temperature. Furthermore, according to the observations made by [11], rock samples subjected to heat treatment changed physical appearance upon the heating process (Figure 4(b)).

Below $400^{\circ} \mathrm{C}$, the heated samples were contracted (loss of free water and bound water or incorporation) and seemed to decrease in volume. Conversely, above $400^{\circ} \mathrm{C}$, the volume of heated samples increased remarkably as the temperature increases.

As concerning the sandstones case investigated by [11], it observed a relative change of around $25 \%$ of volume at $1200^{\circ} \mathrm{C}$. However, when the temperature increased, a contraction was first observed and then followed by a volume an expansion.

5.5. Variation of the Thermal Expansion Coefficient as a Function of Temperature. According to [8], thermal expansion is one of the first causes of thermal rock structure damage. When temperature was increased, the rock mineral constituents were subjected to thermal expansion and/or contraction. The thermal expansion was substantially anisotropic and can been amplified by the mineralogical heterogeneity of the rock and then induced expansion inequalities [26, 31, 69, 92]. The differential expansion phenomena cause a stress concentration at the grain boundaries and thus cracking. Generally, the coefficient of thermal expansion of minerals increased with temperature $[15,16,25,42,93]$ as seen in Figure 5. Regarding the quartz monzonite case, an increase in temperature was recorded while it decreased with an increase in confined pressure [70]. In this case, the thermal expansion of plutonic rocks (granite, gabbro) and metamorphic rocks (schist) decreased 

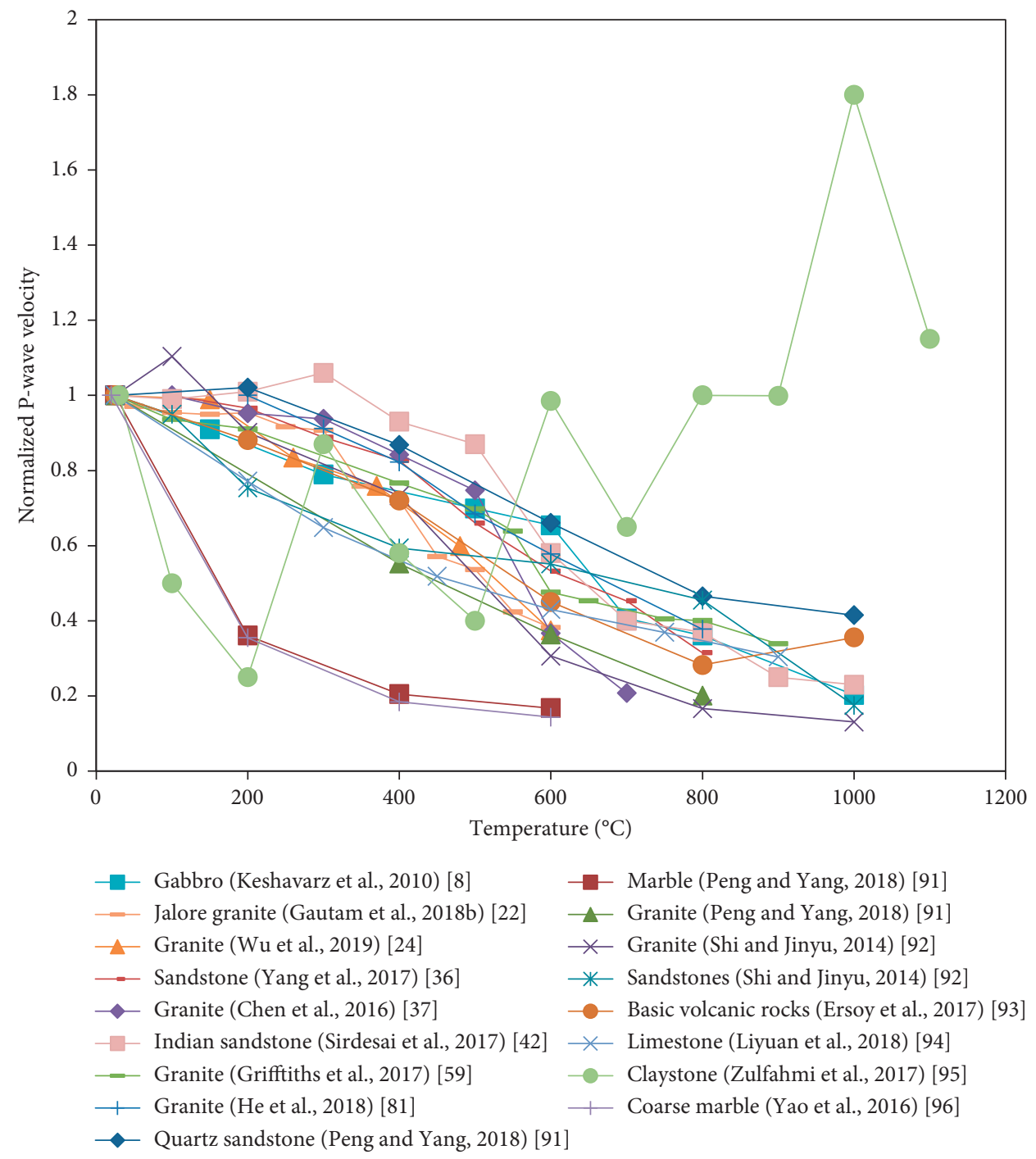

FIGURE 3: Change in normalized wave velocity $V_{p}$ of certain rocks as a function of temperature.

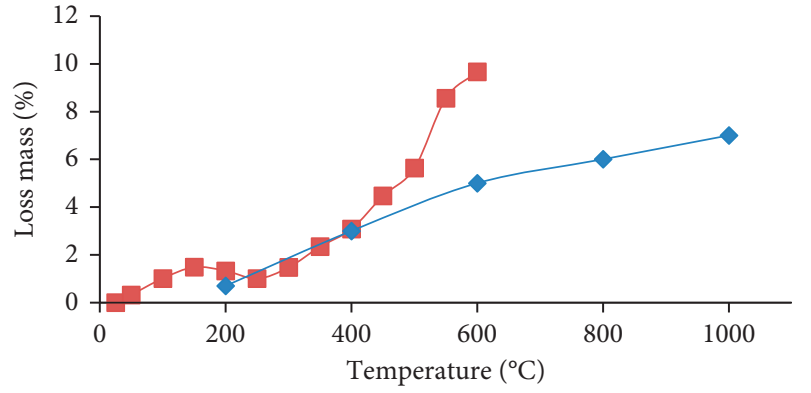

Jalore granite (Gautam et al., 2018b) [22]

$\neg$ Basic volcanic rocks (Ersoy et al., 2017) [93]

(a)

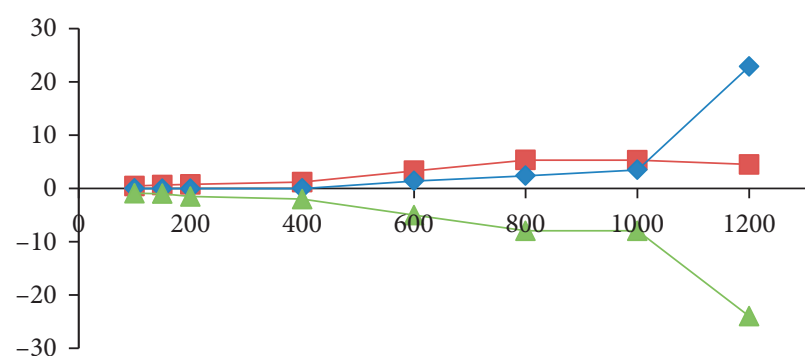

Temperature $\left({ }^{\circ} \mathrm{C}\right)$

$$
\begin{aligned}
& -\Delta \mathrm{m} / \mathrm{m}(\%) \\
& \neg \Delta \mathrm{V} / \mathrm{V}(\%) \\
& -\Delta \rho / \rho(\%)
\end{aligned}
$$

(b)

Figure 4: (a) Evolution of mass loss of basic volcanic rocks as a function of the temperature. (b) Change in volume, mass, and density of sandstone [11]. 


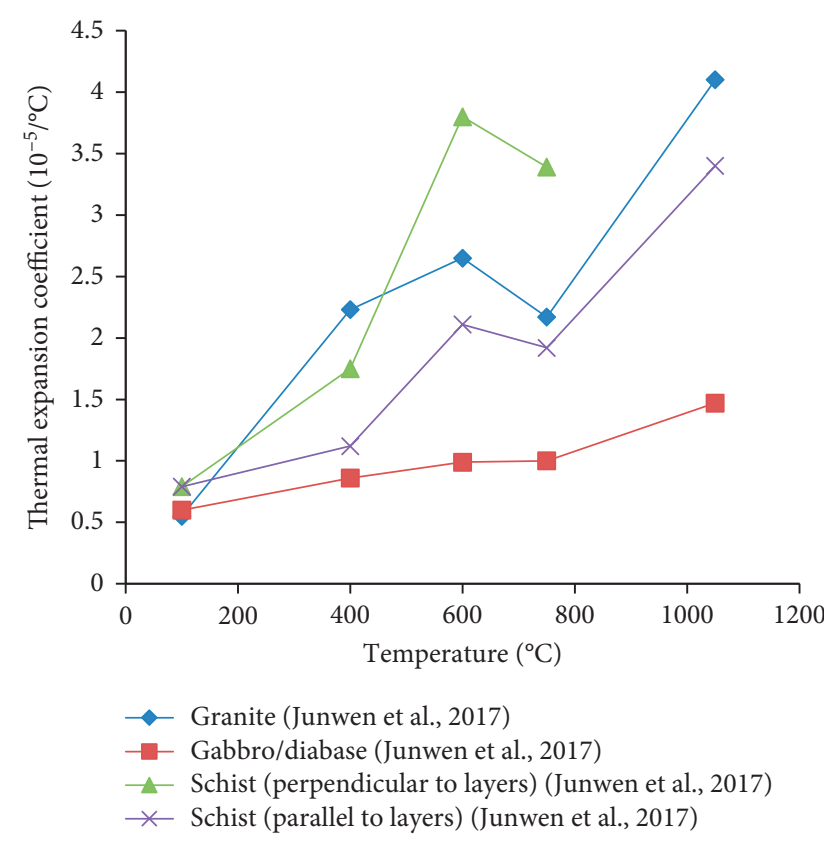

FIgURE 5: Coefficient of thermal expansion of some rocks as a function of temperature [92].

at $600^{\circ} \mathrm{C}$ before drastically decreasing at $750^{\circ} \mathrm{C}$. In light to this behavior, we can conclude that considering the mineralogical heterogeneity, this parameter was uniform for these rocks.

The thermo-physical properties such as porosity, permeability, elastic wave velocity, density, and thermal expansion coefficient of rocks have been permitted to have more data from mechanical parameters. We have observed an increase and/or decrease in these parameters with high temperature for any rock. At the end of this section, we can conclude that severe modification in physical properties induced certainly a great impact on mechanical properties due to its mineralogical composition and geological context.

\section{Influence of High Temperature on the Mechanical Properties of Rocks}

The mechanical properties of rocks subjected to high temperature treatment depend on their microstructure, their mineralogical composition, and test conditions (heating/ cooling and mechanical load). At high temperature, mechanical properties were dramatically modified to have a great influence on the rock structures deformation and stability [5, 8, 23, 94]. Yang et al. [36] reported a great dependence between strains, microcracks, compressive strength, behavior of acoustic emission with the temperature, and damage of a granite rock.

6.1. Normalized Young's Modulus Evolution Depending on the Temperature. The evolution of the elasticity versus temperature module was determined from the stress-strain curves in uniaxial compression tests. Several studies $[5,11,51,53,70,92,94]$ were based on the influence of temperature using the residual Young modulus parameter.
In general, there was a decrease in the normalized Young's modulus as a function of temperature (Figure 6).

From this figure, the normalized elasticity modulus of plutonic rocks decreased uniformly with temperature for other rocks as sedimentary rocks (diabase, sandstone, and mudstone) and metamorphic rocks (schist); this parameter did not present a uniform behavior [95-97]. We observe at $400^{\circ} \mathrm{C}$ the decrease in normalized elasticity modulus of more than $90 \%$ of rocks. Then, at $600^{\circ} \mathrm{C}$, this normalized index of all rocks decreases at $100 \%$. This implies the great destruction of the rock structure. Therefore, we can conclude that $400^{\circ} \mathrm{C}$ of temperature can considerably attenuate the normalized elasticity modulus of all rocks.

Diaz [2] performed experiments on three different rock types (marble, limestone, and sandstone) and confirmed this similar characteristic behavior of Young's modulus. Indeed, some results obtained were quite dispersed but can be explained by the heterogeneity of different rocks on the one hand and the experimental conditions and parameters on the other hand. Experimental work of [8] carried out on gabbros also reported a drop in the dynamic Young's modulus with an increase in temperature. Accordingly, the authors of [11] who performed experiment on sandstone also reported the same behavior. However, it is noticed that beyond $800^{\circ} \mathrm{C}$, the dynamic Young's modulus decreased slightly [11].

In the case of real-time processing, we noted the continual decrease in the normalized modulus of elasticity at $300^{\circ} \mathrm{C}$.

Mambou et al. [94], Budiansky and O'connell [98], and A. Török and Á. Török [99] performed works on granite at $23^{\circ} \mathrm{C}, 300^{\circ} \mathrm{C}, 600^{\circ} \mathrm{C}$, and $900^{\circ} \mathrm{C}$ and reported that below $300^{\circ} \mathrm{C}$, the elasticity modulus increased slowly whereas above this temperature the modulus decreased considerably with an increase in heat.

6.2. Poisson's Ratio Variation as a Function of Temperature. Poisson's ratio is a mechanical characteristic parameter of materials, particularly hard rock. Measurements of dynamic and static Poisson ratio performed by [11] on sandstone are depicted in Figure 7. These curves demonstrated how the dynamic and static Poisson coefficients changed with temperature and confirmed once more the drastic variation in the physical characteristics of the material based on high temperature. Therefore, Poisson's ratio increased significantly at $750^{\circ} \mathrm{C}$, which induced damage of rock material. The measurements investigated by [11] demonstrated a random variation or even dispersive static Poisson's ratio with increasing temperature. We can conclude that before $600^{\circ} \mathrm{C}$, an antinomic phenomenon was created in rock material. However, above $750^{\circ} \mathrm{C}$, Poisson's coefficient has been increased drastically implying that rock structure was destroyed. However, dynamic Poisson's ratio before heating is up than the dynamic Poisson's ratio after heating of sandstone sample before $1000^{\circ} \mathrm{C}$ reported in [11].

6.3. Uniaxial Compressive and Tensile Strength Evolution as a Function of Temperature. Figure 8(a) compiles the results of the normalized compressive strength tests conducted on 


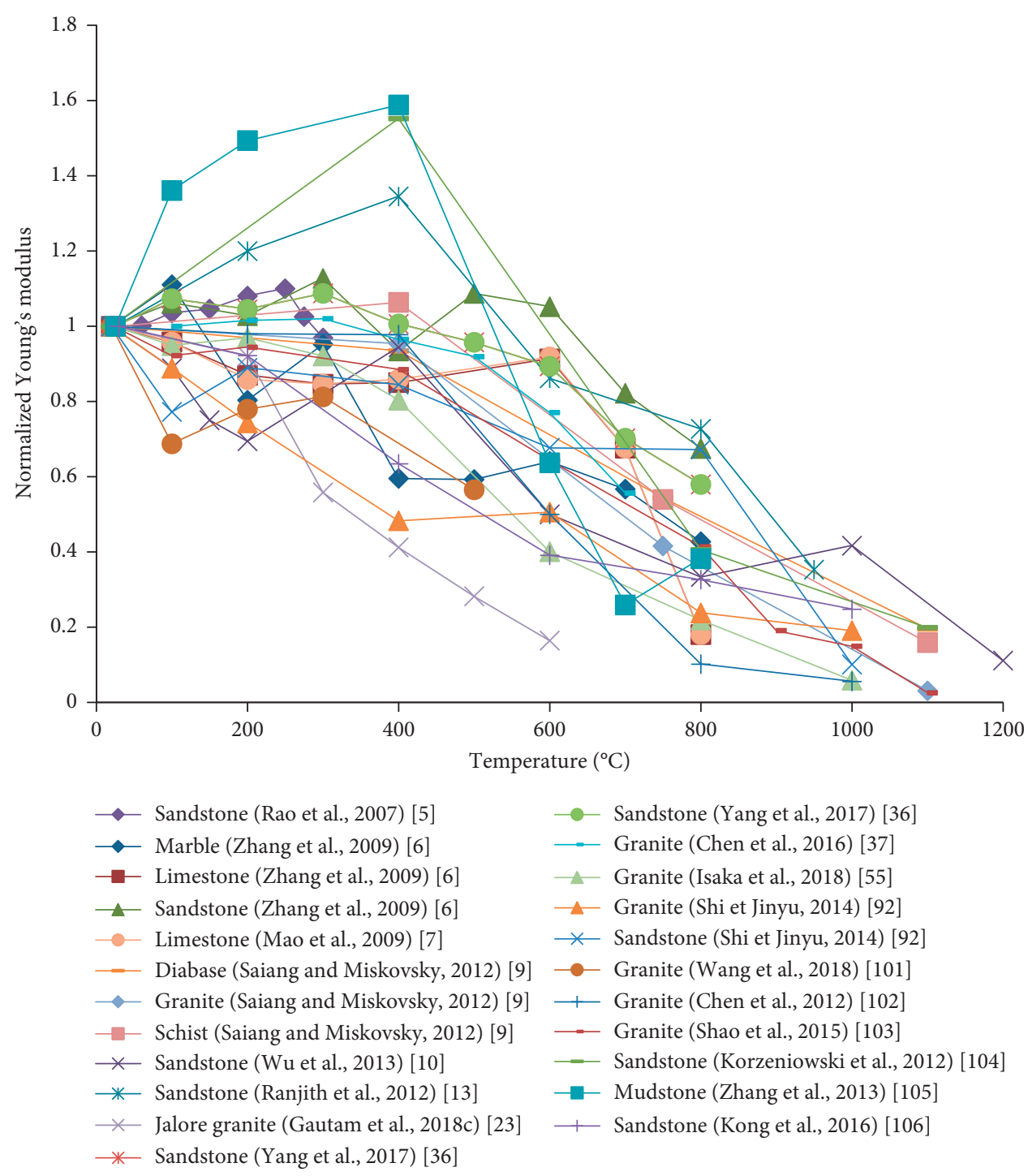

FIGURE 6: Normalized Young's modulus of certain rocks as function of temperature.

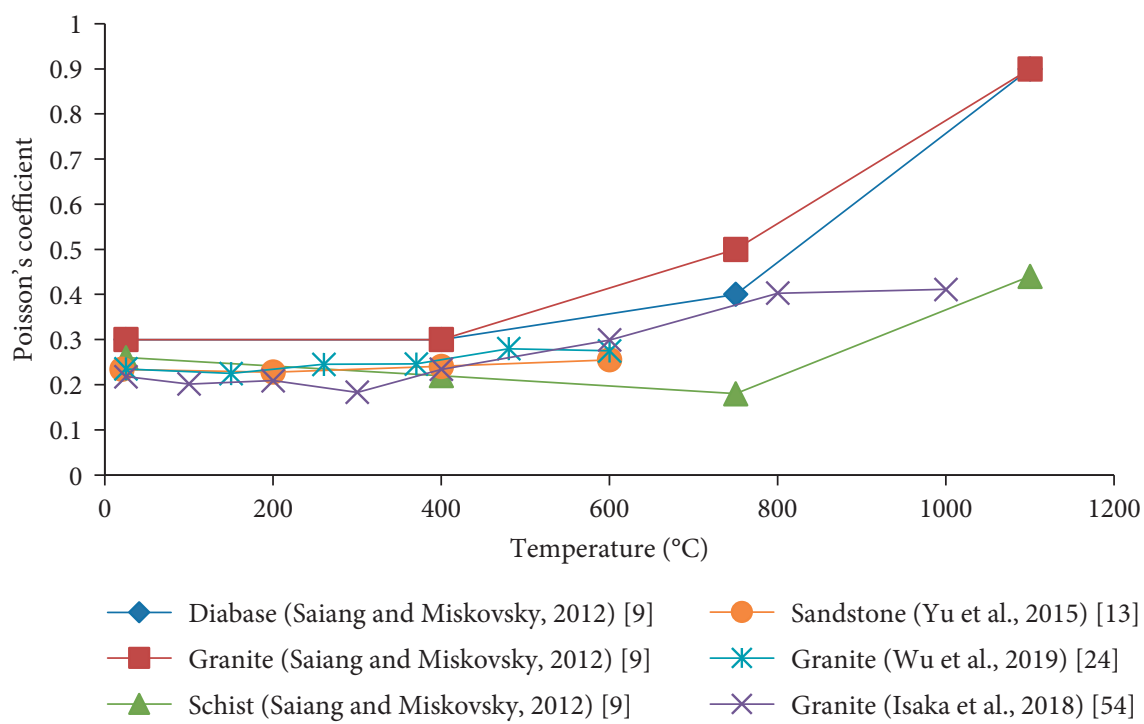

FIgURe 7: Static Poisson's ratio of sandstone as a function of temperature. 


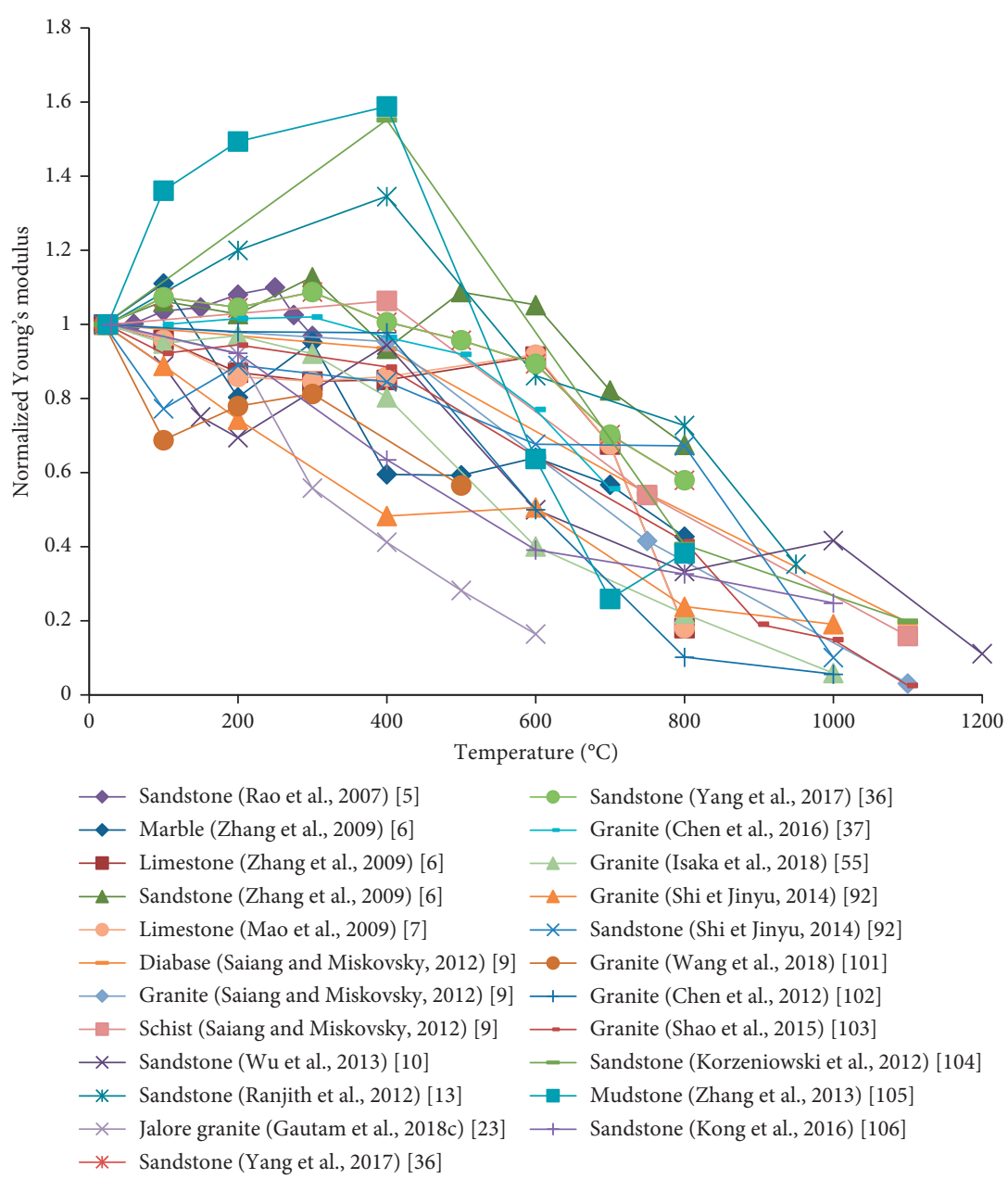

(a)

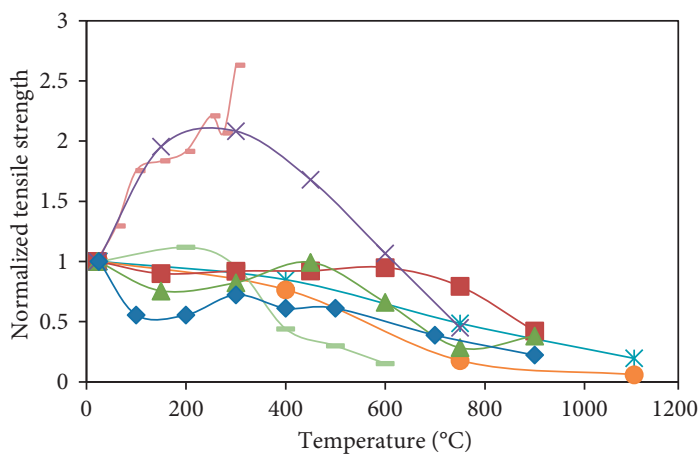

-- Sandstones (Rao et al., 2007) [5]

* Diabase (Saiang and Miskovsky, 2012) [9]

-- Granite (Saiang and Miskovsky, 2012) [9]

_- Jalore granite (Gautam et al., 2018c) [23]

- Maulbronner sandstone (Akos and Hajpal, 2005) [52]

- - Rezi sandstone (Akos and Hajpal, 2005) [52]

$\leftarrow$ Rohrschacher sandstone (Akos and Hajpal, 2005) [52]

$\multimap$ Gneiss (Mambou et al., 2017) [76]

(b)

FIGURE 8: (a) Normalized compressive strength of certain rocks in relation to temperature. (b) Normalized tensile strength of certain rocks as function of temperature. 
many different rocks [95-97, 100-102]. There was an increase and decrease in normalized compressive strength at various high temperatures. This increase results from the closure of existing microcracks and intensification of the microstructure with volatilization of water contained in the internal structure of rock which give rise to the greater number of pores. In this figure, we observed that below $400^{\circ} \mathrm{C}$, the normalized compressive strengths decreased while others increase and vice versa. It appeared clearly that normalized compressive strength of rocks was not uniform for all rock type which was justified by an antinomic phenomenon. This was due to the closure of pre-existing pores and microcracks in the case of increased normalized compressive strength. In addition, the reopening of pores and the densification of cracks networks lead to a decrease in normalized compressive strength. Above $400^{\circ} \mathrm{C}$, almost all normalized compressive strength decrease. From $800^{\circ} \mathrm{C}$, there was a drastic drop in compressive strength, leading to vulnerability of rock. Therefore, we found that in these rocks, mudstone was the one that was most sensitive to heat treatment.

Especially in the case of real-time temperature heat treatment, the compressive strength of rocks decreases faster than that of cooled rocks. It is confirmed in [5-7] where $300^{\circ} \mathrm{C}$ seems to be the temperature at which the decrease occurs continuously. It may be due to mineralogical composition with its anisotropic thermal influence and chemical reactions that take place during thermal treatment. Compared with the case of rocks treated in real-time processing, we observe that the residual compressive strength is reduced at about $75 \%$ at $600^{\circ} \mathrm{C}$. It would be due to the antinomic phenomenon.

In Figure $8(\mathrm{~b})$, from $300^{\circ} \mathrm{C}$, there was a gradual decrease in normalized tensile strength that tends to zero as temperature increases. Compared with normalized compressive strengths, normalized tensile strengths were very low.

A significant loss of the mechanical performance of the rock is a considerable gain in mechanical energy to be used for the fragmentation of a specimen. Indeed, this result explained why artisan miners or some engineers used fire to heat rock first before using a mechanical tool to fragment the hard rock in artisanal quarries and in some rock engineering applications. Conversely, the strength of the clayey sandstones was even improved after the heat treatment. It can be concluded that the behavior of sandstone under heat treatment is controlled by its composition and diagenesis $[2,36]$.

Experimental work of Keshavarz et al. [8] performed on gabbros confirmed a gradual decrease in the ultimate strength depending on an increase in temperature. Wu et al. [11], Tian et al. [84], Peng and Yang [103], Lintao et al. [16], and Gautam et al. $[14,15]$ performed similar experiments on sandstone, and they reported the same observations after heat treatment temperature above $100^{\circ} \mathrm{C}$. At the same time, Rao et al. [5] indicated the similar conclusion under realtime temperature. Sygala et al. [104] demonstrated that apart from temperature, the nature of changes in compressive strength and Young modulus of rocks can be analyzed by using in addition to thermal treatment other parameters like mineral composition, density, and porosity [1]. Other authors [105-108] considered in their work that a fracture toughness of stress has no negligible effect on its redistribution after loading, thus can cause damage of the rock. However, this damage was generally induced when the anisotropy and inhomogeneity of the rocks were considered $[99,105,109,110]$. On the other hand, Gautam et al. [15] realized that rocks with high proportion in calcite and an inhomogeneous microstructure have a semiplastic behavior at high temperature.

\subsection{Mechanical Behavior of Rocks at High Temperature.} Regarding different experimental works, we found that the variations of temperatures have a significant influence on the behavior of hard rock. Indeed, each stress-strain curve taken with a temperature was characterized mainly by its slope (Young's modulus) in the linear portion and the culminant point which represented ultimate strength (Figure 9(a)) with marble rock (metamorphic rock), (Figure 9(b)) with granite rock (plutonic rock), (Figure 9(c)) with limestone (sedimentary rock), and (Figure 9(d)) with sandstone (sedimentary rock). In general, we noticed that the slope and the maximal point of each of these curves decreased with increase in temperature. In Figure 9(e), it was generally observed that rock strains increase with temperature [10, 15]. Therefore, the thermal strain of the rock mass was found to be irreversible. However, we have an antinomic phenomenon in this case up to $300^{\circ} \mathrm{C}$. Heat strengths depend on the type of cementing mineral, the amount of cement, and the grain size. It does explain at $600^{\circ} \mathrm{C}$ which is the critical thermal load. At this temperature, peaks stress is around $59 \mathrm{MPa}$ for metamorphic rock, $70 \mathrm{MPa}$ for plutonic rock, $105 \mathrm{MPa}$ for sedimentary rock, and $55 \mathrm{MPa}$ for other sedimentary rock cited in this part. Finally, we can conclude that the development of microcracks at grain boundary and mass loss imply these peak stress which present the decrease in rock rigidity. The nature of the changes varies for different types of rocks.

\section{Thermal Damage}

Damage of material is a concept that is increasingly explored and characterizes the state of degradation of this material. In rock engineering, several authors have already expressed their opinions $[15,19,22,23,51,65,101,102,111-114]$. From Figure 10 , it can be seen that between $300^{\circ} \mathrm{C}$ and $500^{\circ} \mathrm{C}$, the damage of most rocks is increased continuously $[115,116]$. It is the same behavior above $600^{\circ} \mathrm{C}$. In this case, we can conclude that the antinomic phenomenon was confirmed which is predicted by Figures 6, 8(a), and 9(a). We observed that the damage of major rocks tends to stabilize around $600^{\circ} \mathrm{C}$ certainly due to the reversible reaction of $\alpha$ quartz to $\beta$ quartz occurred at $573^{\circ} \mathrm{C}$. General damage reflects the whole rock failure process of microcracks compaction, initiation, expansion, and destruction at high temperature.

Few works have been realized in the laboratory on influence of thermal cycles. In addition, all the plastic strains 


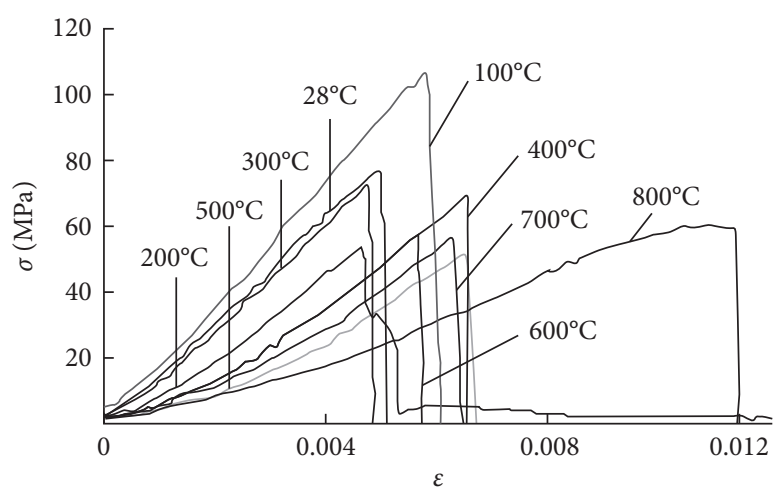

(a)

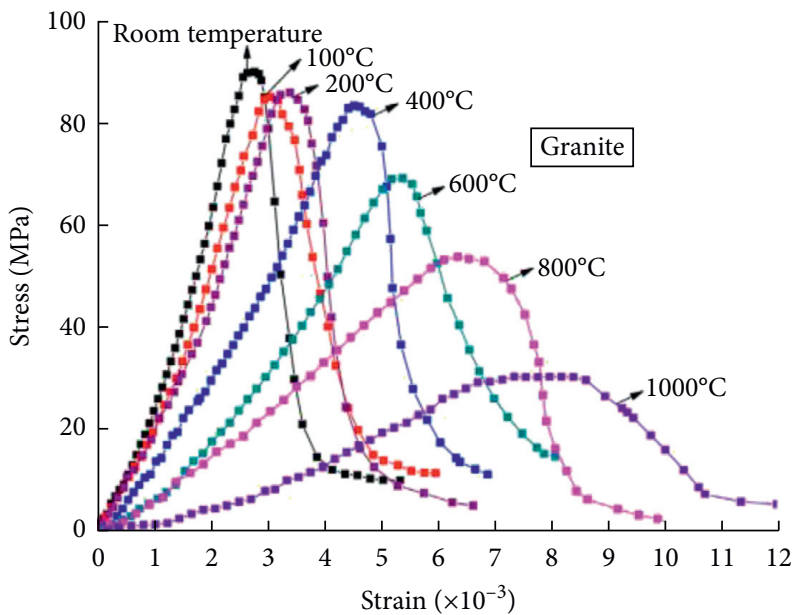

(b)

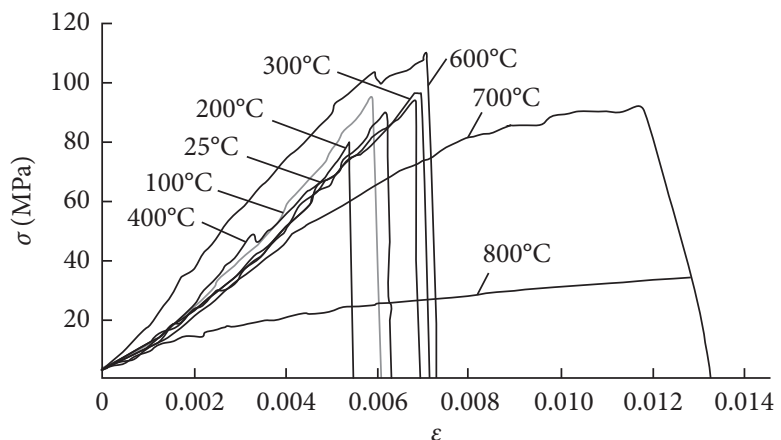

(c)

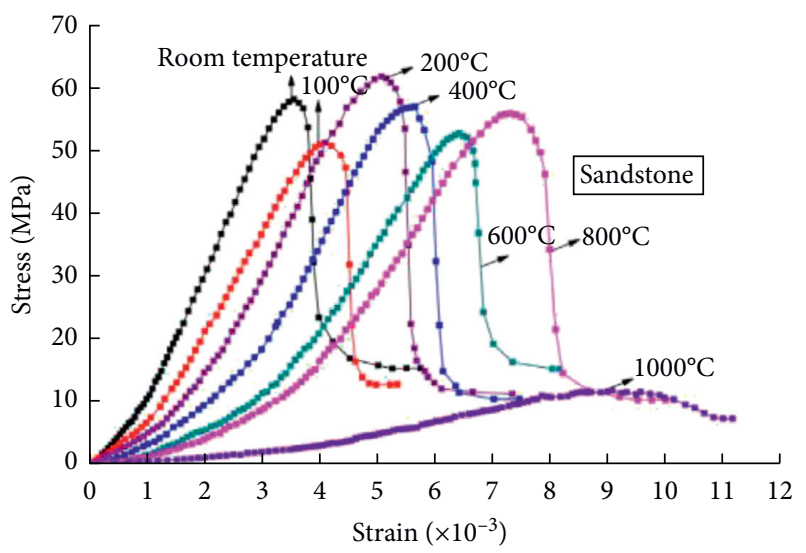

(d)

Figure 9: Continued. 


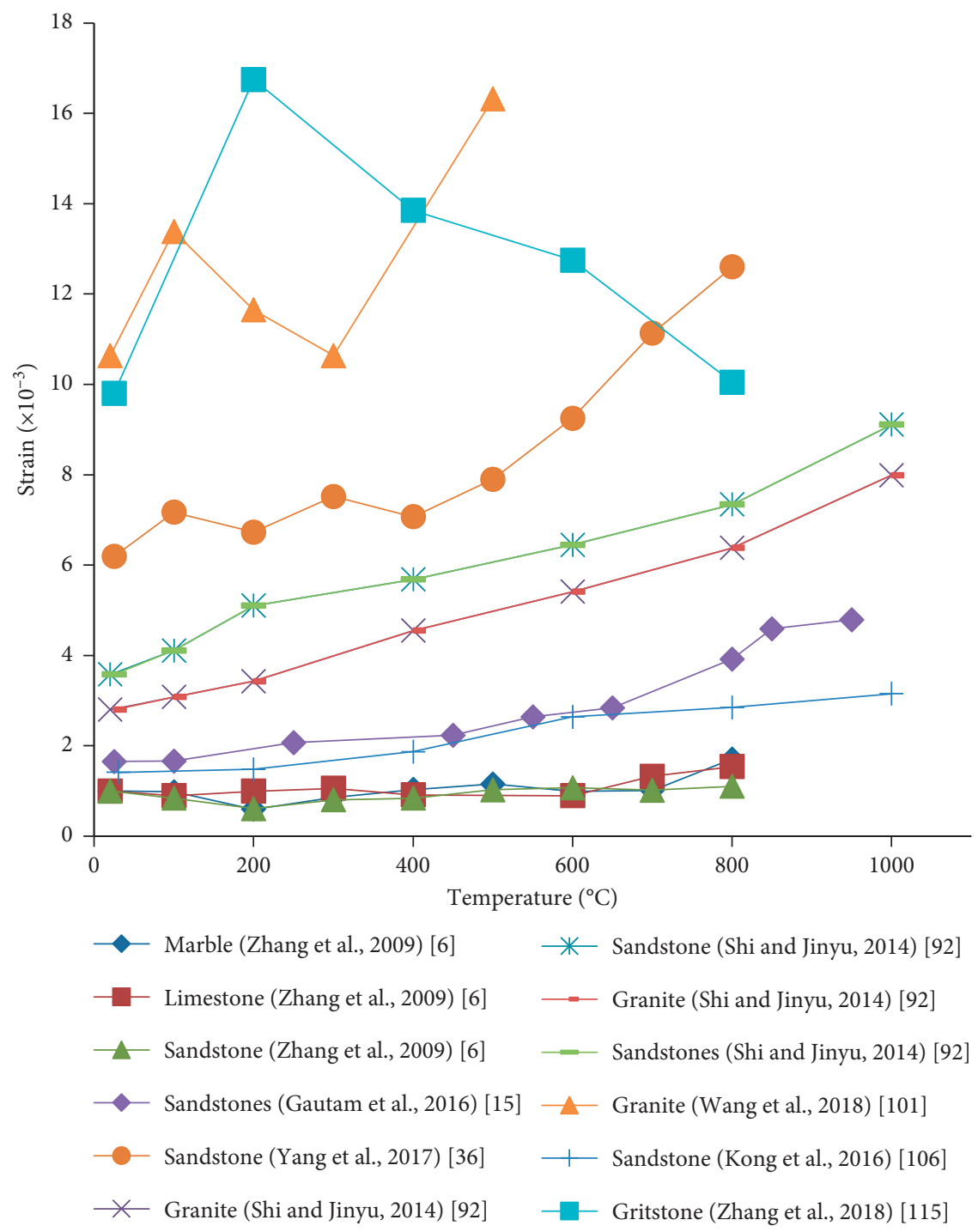

(e)

FiguRE 9: Stress-strain curves at high temperature of (a) marble [6], (b) granite [111], (c) limestone [6], (d) sandstones [111], and (e) peak strain-temperature curves of certain rocks [108].

can be also explained by the phenomenon of failure. The thermal fatigue phenomena and thermal shock can cumulate if the variations of temperature are randomly distributed. Otherwise, few references have indicated the modeling of thermal fatigue of rocks while this phenomenon is described very well on other material as steel beam or wood beam. It is proved that when the number of thermal cycles increases, the strength and rigidity of rock decrease. Recently, Sha et al. [117] proved in their review that the brittle-ductile transition of minerals at high temperature is produced and has a significant influence on mechanical properties of rocks. Liu et al. [118] confirmed the phenomenon using a statistical damage constitutive model of granite. Consequently, the changes of internal structure of rocks affect seriously both tensile strength and brittleness of that rock and thus damage of rock.

\section{Theory}

The development of thermoelasticity has increased favorably for the phenomenological understanding of thermomechanical properties of the rocks studied, most of them experimentally. However, none of the previously cited works and to our knowledge those not cited here do not address the problem in the sense of modeling and numerical analysis of stresses and strains of hard rocks under mechanical and thermal stresses. Mambou et al. [94, 119] have considered a rock specimen under mechanical load and fire.

Based on Newton's second law, Mambou et al. [119] established the rate-equation model of sandstone rock specimen under uniaxial mechanic load and fire. They applied thermal load ranging from $25^{\circ} \mathrm{C}$ to $900^{\circ} \mathrm{C}$. Mambou et al. introduced in their model the material nonlinear stress/ 

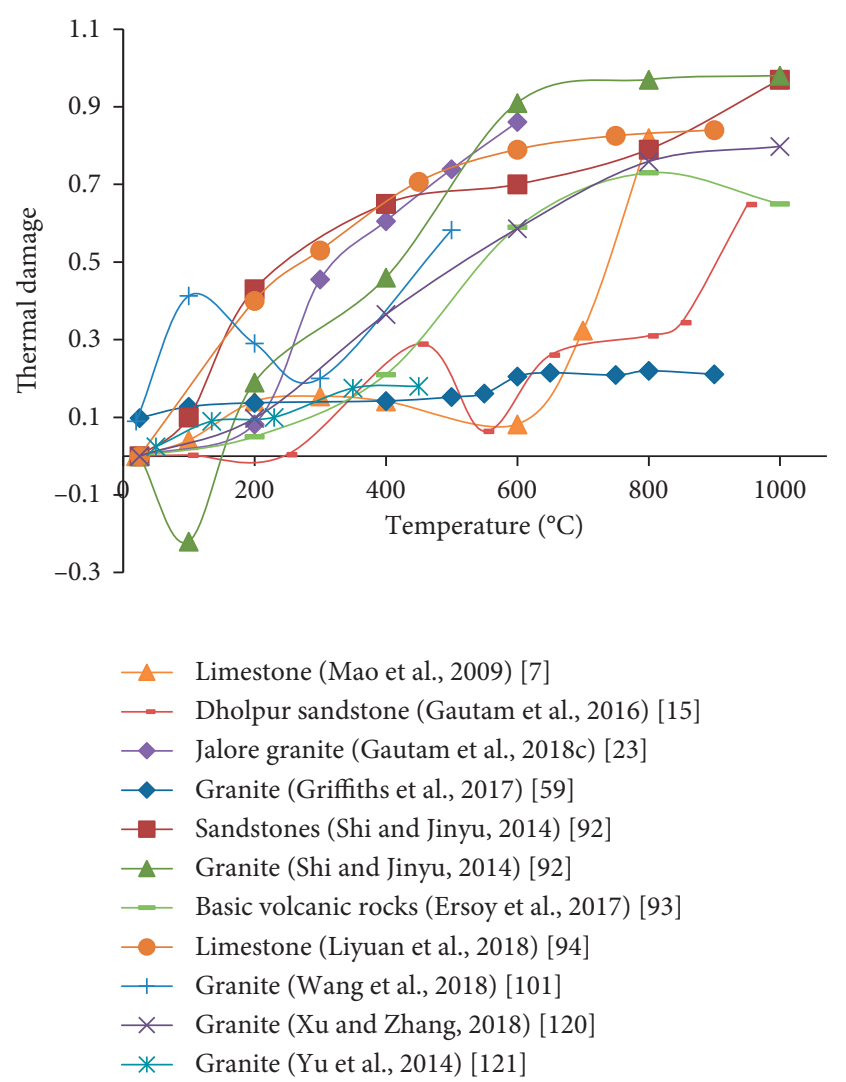

FIgURE 10: Evolution of thermal damage of certain rocks.

strain relationship, and the effect of material nonlinearity was analyzed.

The effect of mechanical load and thermal treatment on rock specimen was numerically investigated. Mambou et al. showed that the amplitude of the internal stress gradually decreases when the temperature increases. The analyses of the internal stress revealed that the combined effects of a thermal treatment and mechanical load on the specimen lead to the rapid damage of a specimen. Heating the specimen to $100^{\circ} \mathrm{C}$ reduced the internal stress of around $30 \%$ $[94,119]$.

Mambou et al. found that $450^{\circ} \mathrm{C}$ was a critical temperature of damage for the physical and mechanical properties of sandstone and granite. Above $450^{\circ} \mathrm{C}$ of heating, the internal stress tends to fall to zero. Moreover, above this temperature, a significant reduction in strength occurs. This result showed the loss in rigidity of sandstone and granite when the temperature increased and revealed that the fire reduced the mechanical performance of hard rocks significantly. The material nonlinearity parameter slowly affected the thermal damage of sandstone. Their model was validated by numerical simulation reported in [94] without parameter $\beta$. Their results can be also useful to characterize mechanical degradation of rocks. It is also seen that their results prevent dramatic consequences for geoengineering structure which is experienced with thermal load.

Based on the Weibull distribution, Wang et al. [100] developed a model that combines heat treatment and dynamic mechanical loading on granite specimen to appreciate the behavior of its mechanical parameters, stress, and strain curves in particular and dynamic strength and Young's modulus. Their sample is heated to $20^{\circ} \mathrm{C}, 100^{\circ} \mathrm{C}, 200^{\circ} \mathrm{C}$, $300^{\circ} \mathrm{C}$, and $500^{\circ} \mathrm{C}$ at a rate of $10^{\circ} \mathrm{C} / \mathrm{min}$. This model showed the strain rate of the specimen as well as the heat inducing damage. At the end of their work, they found that scale parameter has a major influence on stress and strain while the increase in viscous coefficient increased the strength of rock specimen. They also concluded that the model predicts both the effects of strain rate and temperature on the selected specimen [109]. They reported that there is a good agreement observed between the measured and calculated results for each combination of treatment temperature and strain rate.

Yang et al. [120] combined their experimental work on granite specimens with the numerical model and allowed characterizing the behavior of the mechanical parameters related to failure mechanism in granite specimens subjected to temperatures ranging from $25^{\circ} \mathrm{C}$ at $900^{\circ} \mathrm{C}$. The model was built on two-dimensional particle flow code $\left(\mathrm{PFC}^{2 \mathrm{D}}\right)$. Granite specimens studied mainly contain three holes which were placed in three directions. Following the axis of the specimen, the authors of [120] specified the orientation $\beta=$ $0^{\circ} \mathrm{C}$ (horizontal model) on axis, $\beta=45^{\circ} \mathrm{C}$ in relation to this axis (diagonal model), and $\beta=90^{\circ} \mathrm{C}$ perpendicular to this axis (vertical model). The numerical analysis was done by modifying the radii of holes as well as the applied force. They noted that the mechanical parameters such as stress, strain, and elasticity modulus presented three particular zones where these parameters have practically the same behavior: $T \leq 150^{\circ} \mathrm{C}, 150^{\circ} \mathrm{C} \leq T \leq 600^{\circ} \mathrm{C}$, and $600^{\circ} \mathrm{C} \leq T \leq 900^{\circ} \mathrm{C}$. Yang et al. also noted that the « diagonal model » easily undergoes the propagation of microcracks within it compared with the «horizontal model» and «vertical model» since shear stress was very high in this case. Furthermore, high temperatures considerably affect the force field applied. Their numerical results were similar to the experimental obtained results. Previously, Yang et al. [121] investigated the process of intergranular and intragranular microcracks expansion within Australian Strathbogie granite specimen at temperature levels of $23^{\circ} \mathrm{C}, 100^{\circ} \mathrm{C}, 200^{\circ} \mathrm{C}, 400^{\circ} \mathrm{C}, 600^{\circ} \mathrm{C}, 800^{\circ} \mathrm{C}, 900$ $\mathrm{C}, 1000^{\circ} \mathrm{C}$, and $1100^{\circ} \mathrm{C}$ using also $\mathrm{PFC}^{2 \mathrm{D}}$ code. They found that below $400^{\circ} \mathrm{C}$, the total number of microcracks was constant. On the other hand, this number increased linearly above this temperature.

A statistical constitutive model of rock thermal damage under triaxial compression condition was established by $\mathrm{Xu}$ et al. [113], and they have showed that a brittle-plastic strain is made with the critical confining pressure of about 35.40 MPa. They demonstrated that also peak stress, residual stress, and peak strain increase with confining pressures. The authors of [113] indicated that for different rock strength criteria, it is important to take into account the statistical distribution function according to the practical engineering.

Recently, in agreement with previous literature experimental work, Foguieng et al. [122] explored in 3D the anisotropic and nonlinear mechanical behavior of Tournemire argillite material under dynamic loading and thermal treatments at $20^{\circ} \mathrm{C}, 100^{\circ} \mathrm{C}, 300^{\circ} \mathrm{C}, 500^{\circ} \mathrm{C}, 600^{\circ} \mathrm{C}, 700^{\circ} \mathrm{C}$, 
$900^{\circ} \mathrm{C}$, and $1120^{\circ} \mathrm{C}$. Using the inhomogeneity of rock material and the material nonlinearity, they reported that the critical temperature at which rock material is seriously damaged is $500^{\circ} \mathrm{C}$. The authors of [122] proved that the material inhomogeneity has a great influence on internal stress of that rock. They also showed that the increase in peak stress is about $75 \%$ after $2.9 \mathrm{~min}$ for an inhomogeneity of material in the range of 2995-3256.010.

\section{Cool and Heat Tests Comparison}

Few works have been reported on mechanical parameters when rock specimens were submitted simultaneously on thermal load and mechanical or physical tests. It was important to evaluate mechanical parameters under thermal load simultaneously as in engineering projects. This situation gives in real-time under high temperature the damage of rock material. For one thermal cycle of the hard rock, uniaxial stress gave more informations than other destructive tests [25]. The authors of $[12,54,75,123]$ revealed that using the nondestructive method of P-wave velocity change with temperature. The authors of [102] showed that electromagnetic radiation in terms of intensity increased at the same stress level. The authors of $[54,89,102]$ illustrated that when the stress approaches the peak strength, the recorded acoustic emission activities mostly accumulated. We noted that under thermal load, the mechanical parameters which have been determined tend to reflect finally the reality of engineering projects.

\section{Conclusion}

The review of both theoretical and experimental research studieson the effect of temperature on hard rocks was discussed in this paper. The response of rocks at high temperature induced by fire highly depends on the composition of an individual rock. Minerals, fluids inclusions, and initial damage of natural rocks have a significant effect on their mechanical properties. The loss in mass and thermal conductivity in volcanic's rock was drastically observed at low temperature of about $200^{\circ} \mathrm{C}$ and imply approximately $80 \%$ of the increase in porosity above $500^{\circ} \mathrm{C}$. Forming with white and black minerals, plutonics and metamorphic rocks got significant damages at $600^{\circ} \mathrm{C}$ which can be considered as critical temperature. Literature results showed that at high temperatures (above $400^{\circ} \mathrm{C}$ ), elastic modulus and compressive and tensile strengths decreased with an increase in temperature. However, at low temperature (less than $400^{\circ} \mathrm{C}$ ), it has been noticed that a converse phenomena such as intensification and cracking occur. At this temperature, permeability increased significantly with the applied containment pressure, resulting in high rock porosity produced around $300^{\circ} \mathrm{C}$. On the other hand, other works presented critical temperature at which the mechanical properties of rocks were severely modified as $600^{\circ} \mathrm{C}$. However, it is important to take into account the initial damage of the used specimen in order to better assess the mechanical behavior of the rock structure. Different gaps and inconsistencies are due to difference of critical temperature presented in the literature review. There is $100^{\circ} \mathrm{C}$ gap between the results obtained in real-time and those obtained after cooling. Moreover, $300^{\circ} \mathrm{C}$ can be considered as the critical temperature for real-time temperature heat treatment at which rocks lose almost about $80 \%$ of their performance.

In general, using destructive and nondestructive methods, some parameters like the normalized modulus of elasticity as well as the normalized compressive strength of explored rock demonstrated a significant decrease of about $75 \%$ of hard rocks when temperatures were above $600^{\circ} \mathrm{C}$. Therefore, we considered this temperature as its critical thermal load for hard rock thermal treatment. At this critical temperature, the volume expansion was almost $8 \%$ whereas above this critical value, an increase in volume of about $25 \%$ was achieved. From $400^{\circ} \mathrm{C}$ to $600^{\circ} \mathrm{C}$, a serious decline in the mechanical properties of the specimen was registered. However, few works have reported under real-time temperature for mechanical characteristics. From our point of view, it was important to evaluate the mechanical parameters under thermal load simultaneously as in engineering projects. When we have observed the increase in mechanical parameters (normalized Young's modulus and normalized compressive strength) of granite of one country, for example, we have observed at one temperature (up to $400^{\circ} \mathrm{C}$ ) the decrease in this mechanical parameter of another granite specimen of other country implying the contradiction with the presence of antinomic phenomena.

Compared with other rocks, sandstone, granite, and argillite present the model whose behaviors with high temperature are too much explored accordingly with experiments. Argillite at $200^{\circ} \mathrm{C}$ and sandstone and granite at $400^{\circ} \mathrm{C}$ undergo seriously damage. However, it is difficult to predict the behavior at high temperature of volcanic rocks like basalt and metamorphic rocks like gneiss. The rocks with a high content of clay minerals were not damaged by the heat treatment due to its ability to regulate quartz expansion. Moreover, their strength can even be improved by elevated temperatures thanks to the dehydroxylation of clays. Then, clay rocks are more suitable for low temperature applications. It is therefore recommended to use the materials within certain temperature range and also with the addition of other materials to enhance the strength due to the thermo-physical properties which have a vital role on the thermomechanical properties and affect the rigidity and durability of rocks.

Most of experimental works have been done to determine the physical and mechanical behavior without taking to account the inhomogeneity and anisotropy of rocks. There are several studies which did not do with that consideration. We have also noted that it is necessary to intensify works in terms of modeling and numerical analysis to predict in real-time the mechanical behavior of rocks and then the rigidity of rock and the stability of building structure which are accidentally submitted to fire.

The results in this review provide some sights in understanding the behavior of rock type in response of thermal load.

\section{Conflicts of Interest}

The authors declare that they have no conflicts of interest. 


\section{References}

[1] M. Keppert, J. Fořt, A. Trník et al., "Behavior of sandstones under heat treatment," International Journal of Thermophysics, vol. 38, no. 4, pp. 1-9, 2017.

[2] P. M. Diaz, "Rock mechanical properties of granite/clay/ basalts/argillite/glass and its alterations at different temperatures-a review," Journal of Advances in Civil Engineering, vol. 3, no. 1, pp. 9-20, 2017.

[3] A. M. Van den Kerkhof, J. L. R. Touret, C. Maijer, and J. B. H. Jansen, "Retrograde methane-dominated fluid inclusions from high-temperature granulites of Rogaland, southwestern Norway," Geochimica et Cosmochimica Acta, vol. 55, no. 9, pp. 2533-2544, 1991.

[4] R. Houpert and F. Homand, "Mechanical behavior of rocks as function of temperature," French Review of Geotechnical Engineering, vol. 28, pp. 41-47, 1989.

[5] Q.-H. Rao, Z. Wang, H.-F. Xie, and Q. Xie, "Experimental study of mechanical properties of sandstone at high temperature," Journal of Central South University of Technology, vol. 14, no. 1, pp. 478-483, 2007.

[6] L. Y. Zhang, X. B. Mao, and A. Lu, "Experimental study on the mechanical properties of rocks at high temperature," Science in China Series E: Technological Sciences, vol. 52, pp. 641-646, 2009.

[7] X.-B. Mao, L.-Y. Zhang, T.-Z. Li, and H.-S. Liu, "Properties of failure mode and thermal damage for limestone at high temperature," Mining Science and Technology (China), vol. 19, no. 3, pp. 290-294, 2009.

[8] M. Keshavarz, F. L. Pellet, and B. Loret, "Damage and changes in mechanical properties of a gabbro thermally loaded up to $1,000^{\circ} \mathrm{C}$," Pure and Applied Geophysics, vol. 167, no. 12, pp. 1511-1523, 2010.

[9] C. Saiang and K. Miskovsky, "Effect of heat on the mechanical properties of selected rock types-a laboratory study," in Harmonising Rock Engineering and the Environment, pp. 15-22, CRC Press, Boca Raton, FL, USA, 2012.

[10] P. G. Ranjith, D. R. Viete, J. C. Bai, and M. S. A. Perera, "Transformation plasticity and the effect of temperature on the mechanical behaviour of Hawkesbury sandstone at atmospheric pressure," Engineering Geology, vol. 151, pp. 120-127, 2012.

[11] G. Wu, Y. Wang, G. Swift, and J. Chen, "Laboratory investigation of the effects of temperature on the mechanical properties of sandstone," Geotechnical and Geological Engineering, vol. 31, no. 2, pp. 809-816, 2013.

[12] P. Hartlieb, M. Toifl, F. Kuchar, R. Meisels, and T. Antretter, "Thermo-physical properties of selected hard rocks and their relation to microwave-assisted comminution," Minerals Engineering, vol. 91, pp. 34-41, 2015.

[13] J. Yu, S.-J. Chen, X. Chen, Y.-Z. Zhang, and Y.-Y. Cai, "Experimental investigation on mechanical properties and permeability evolution of red sandstone after heat treatments," Journal of Zhejiang University-Science A, vol. 16, no. 9, pp. 749-759, 2015.

[14] P. K. Gautam, A. K. Verma, S. Maheshwar, and T. N. Singh, "Thermomechanical analysis of different types of sandstone at elevated temperature," Rock Mechanics and Rock Engineering, vol. 49, no. 5, pp. 1985-1993, 2016.

[15] P. K. Gautam, A. K. Verma, M. K. Jha, K. Sarkar, T. N. Singh, and R. K. Bajpai, "Study of strain rate and thermal damage of Dholpur sandstone at elevated temperature," Rock Mechanics and Rock Engineering, vol. 49, no. 9, pp. 3805-3815, 2016.
[16] Y. Lintao, A. M. Marshall, D. Wanatowski, R. Stace, and T. Ekneligoda, "Effect of high temperatures on sandstone-a computed tomography scan study," International Journal of Physical Modelling in Geotechnics, vol. 17, no. 2, pp. 1-16, 2017.

[17] L. Ming, M. Xianbiao, P. Hai, C. Yanlong, W. Yu, and Z. Lianying, "Effects of heating rate on the dynamic tensile mechanical properties of coal sandstone during thermal treatment," Shock and Vibration, vol. 2017, Article ID 4137805, 11 pages, 2017.

[18] J. Fortin, S. Stanchits, S. Vinciguerra, and Y. Gueguen, "Influence of thermal and mechanical cracks on permeability and elastic wave velocities in a basalt from Mt. Etna Volcano subjected to elevated pressure," Tectonophysics, vol. 503, no. 1-2, pp. 60-74, 2011.

[19] Z. L. Wang and G. Y. Shi, "Effect of heat treatment on dynamic tensile strength and damage behavior of mediumfine-grained huashan granite," Experimental Techniques, vol. 41, no. 4, pp. 365-375, 2017.

[20] W. Zhiliang, T. Nuocheng, W. Jianguo, L. Jiacai, and H. Li, "Experimental study on damage mechanical characteristics of heat-treated granite under repeated impact," Journal of Materials in Civil Engineering, vol. 30, no. 11, pp. 1-8, 2018.

[21] T. D. Rathnaweera, P. G. Ranjith, X. Gu et al., "Experimental investigation of thermomechanical behaviour of clay-rich sandstone at extreme temperatures followed by cooling treatments," International Journal of Rock Mechanics and Mining Sciences, vol. 107, pp. 208-223, 2018.

[22] P. K. Gautam, A. K. Verma, P. Sharma, and T. N. Singh, "Evolution of thermal damage threshold of Jalore granite," Rock Mechanics and Rock Engineering, vol. 51, no. 3, pp. 2949-2956, 2018.

[23] P. K. Gautam, A. K. Verma, M. K. Jha, P. Sharma, and T. N. Singh, "Effect of high temperature on physical and mechanical properties of Jalore granite," Journal of Applied Geophysics, vol. 159, pp. 460-474, 2018.

[24] X. Wu, Z. Huang, H. Song et al., "Variations of physical and mechanical properties of heated granite after rapid cooling with liquid nitrogen," Rock Mechanics and Rock Engineering, vol. 52, pp. 2123-2139, 2019.

[25] Z. Peng and Z.-J. Feng, "Thermal deformation of granite under different temperature and pressure pathways," Advances in Materials Science and Engineering, vol. 2019, Article ID 7869804, 8 pages, 2019.

[26] S. Soprani, F. Marongiu, L. Christensen et al., "Design and testing of a horizontal rock bed for high temperature thermal energy storage," Applied Energy, vol. 251, no. 113345, pp. 1-14, 2019.

[27] D. Healy, E. N. Timms, and A. M. Pearce, "The variation and visualisation of elastic anisotropy in rock forming minerals," Solids Earth, vol. 11, no. 2, pp. 259-286, 2019.

[28] P. K. Gautam, A. K. Verma, M. K. Jha, T. N. Singh, W. Hu, and K. H. Singh, "Experimental investigations on the thermal properties of Jalore granitic rocks for nuclear waste repository," Thermochimica Acta, vol. 681, pp. 1-14, 2019.

[29] G. E. Rivas, W. H. R. Butler, D. Healy, and I. Alsop, "From hot to cold-the temperature dependence on rock deformation processes: an introduction," Journal of Structural Geology, vol. 132, p. 103977, 2020.

[30] Y. N. L. Wong, Y. Zhang, and Z. Wu, Rock strengthening or weakening upon heating in the mild temperature range?" Engineering Geology, vol. 272, no. 105619, pp. 1-32, 2020. 
[31] W. H. Somerton, Thermal Properties and TemperatureRelated Behavior of Rock/Fluids System, vol. 187, pp. 22-29, Elsevier, Amsterdam, Netherlands, 1992.

[32] R. A. Dawe, G. C. Maitland, M. Rigby, and E. B. Smith, "High temperature viscosities and intermolecular forces of quasispherical molecules," Transactions of the Faraday Society, vol. 66, pp. 1955-1965, 1970.

[33] E. Rossi, M. A. Kant, C. Madonna, M. O. Saar, and P. R. Rohr, "The effects of high heating rate and temperature on the rock strength: feasibility study of a thermally assisted drilling method," Rock Mechanics and Rock Engineerin, vol. 51, no. 9, pp. 2957-2964, 2018.

[34] D. Chen and D. Dollimore, "Kinetic analysis of the calcium hydroxide formed in the hydration of pure $\mathrm{C}_{3} \mathrm{~S}$ and with the addition of $\mathrm{Ca}\left(\mathrm{NO}_{3}\right)_{2}$," Journal of Thermal Analysis, vol. 44, no. 5, pp. 1001-1011, 1995.

[35] F. Homand-Etienne, "Mechanical behavior of rocks as a function of temperature," Earth Sciences, vol. 1, no. 46, p. 261, 1986.

[36] S.-Q. Yang, P. G. Ranjith, H.-W. Jing, W.-L. Tian, and Y. Ju, "An experimental investigation on thermal damage and failure mechanical behavior of granite after exposure to different high temperature treatments," Geothermics, vol. 65, pp. 180-197, 2017.

[37] S. Chen, C. Yang, and G. Wang, "Evolution of thermal damage and permeability of Beishan granite," Applied Thermal Engineering, vol. 110, pp. 1533-1542, 2016.

[38] F. E. Heuze, "High temperature mechanical, physical and thermal properties of granitic rocks-a review," International Journal of Rock Mechanics and Mining Sciences \& Geomechanics Abstracts, vol. 20, no. 1, pp. 3-10, 1983.

[39] Z. P. Bazant and M. F. Kaplan, Concrete at High Temperature: Material Properties and Mathematical Models, p. 196, Longman Group Limited, London, UK, 1996.

[40] M. Toifl, R. Meisels, P. Hartlieb, F. Kuchar, and T. Antretter, "Microwave absorption and its thermo-mechanical consequences in heterogeneous rocks," in Geomechanics from Micro to Macro, pp. 1545-1550, CRC Press, Boca Raton, FL, USA, 2014.

[41] Y. Géraud and M. S. Raynaud, "Comparison between connected and overall porosity of thermally stressed granites," Journal of Structural Geology, vol. 14, no. 8-9, pp. 981-990, 1992.

[42] N. N. Sirdesai, B. Mahanta, P. G. Ranjith, and T. N. Singh, "Effects of thermal treatment on physico-morphological properties of Indian fine-grained sandstone," Bulletin of Engineering Geology and the Environment, vol. 78, no. 2, pp. 883-897, 2017.

[43] C. A. Jouenne, Treaty of Ceramics and Mineral Materials, p. 657, 7th edition, Septima, Paris, France, 1980.

[44] A. Menou, G. Mounajed, H. Boussa, C. La Borderie, and K. Lafdi, "Thermal damage approach of concrete: application to specimens subjected to combined compressive and high temperature loads," High Temperature Materials and Processes, vol. 27, no. 1, pp. 23-39, 2008.

[45] P. Vazquez, M. Acuña, D. Benavente, S. Gibeaux, I. Navarro, and M. Gomez-Heras, "Evolution of surface properties of ornamental granitoids exposed to high temperatures," Construction and Building Materials, vol. 104, pp. 263-275, 2015.

[46] Q. Sun, W. Zhang, Y. Zhang, and L. Yang, "Variations of strength, resistivity and thermal parameters of clay after high temperature treatment," Acta Geophysica, vol. 64, no. 6, pp. 2077-2091, 2016.
[47] C. Y. Chen, G. S. Lan, and W. H. Tuan, "Microstructural evolution of mullite during the sintering of kaolin powder compacts," Ceramics International, vol. 26, no. 7, pp. 715-720, 2000.

[48] M. Bellotto, A. Gualteri, G. Artioli, and S. M. Clark, "Kinetic study of the kaolinite-mullite reaction sequence. part I: kaolinite dehydroxylisation," Physics and Chemistry of Minerals, vol. 22, pp. 207-214, 1995.

[49] A. Gualtieri, M. Bellotto, G. Artioli, and S. M. Clark, "Kinetic study of the kaolinite-mullite reaction sequence. part II: mullite formation," Physics and Chemistry of Minerals, vol. 22, pp. 215-222, 1995.

[50] Y. Zhang, X. Zhang, and Y.-S. Zhao, "Process of sandstone thermal cracking," Chinese Journal of Geophysics, vol. 48, no. 3, pp. 722-726, 2005.

[51] X. Meng, W. Liu, and T. Meng, "Experimental Investigation of thermal cracking and permeability evolution of granite with varying initial damage under high temperature and triaxial compression," Advances in Materials Science and Engineering, vol. 2018, Article ID 8759740, 9 pages, 2018.

[52] T. Akos and M. Hajpal, "Effect of temperature changes on the mineralogy and physical properties of sandstone. a laboratory study," Restoration of Building and Monuments, Bauinstandsetzen und Baudenkmalpflege, vol. 11, no. 4, pp. 1-8, 2005.

[53] M. Takarli, W. Prince, and R. Siddique, "Damage in granite under heating/cooling cycles and water freeze-thaw condition," International Journal of Rock Mechanics and Mining Sciences, vol. 45, no. 7, pp. 1164-1175, 2008.

[54] H. A. Abbass, Z. Mohamed, and S. F. Yasir, "A review of methods, techniques and approaches on investigation of rock anisotropy," in Proceedings of the Advances in Civil Engineering and Science Technology, pp. 1-9, Penang, Malaysia, September 2018.

[55] L. A. Isaka Badulla, P. G. Ranjith, T. D. Rathnaweera, M. S. A. Perera, D. Chandrasekharam, and W. G. P. Kumari, "An Influence of thermally-induced micro-cracking under cooling treatments: mechanical characteristics of Australian granite," Energies, vol. 11, no. 6, p. 1338, 2018.

[56] P. Tapponnier and W. F. Brace, "Development of stressinduced microcracks in westerly granite," International Journal of Rock Mechanics and Mining Sciences \& Geomechanics Abstracts, vol. 13, no. 4, pp. 103-112, 1976.

[57] H. F. Wang, B. P. Bonner, S. R. Carlson, B. J. Kowallis, and H. C. Heard, "Thermal stress cracking in granite," Journal of Geophysical Research, vol. 94, no. 2, pp. 1745-1758, 1989.

[58] A. Arena, C. Delle Piane, and J. Sarout, "A new computational approach to cracks quantification from $2 \mathrm{D}$ image analysis: application to micro-cracks description in rocks," Computers \& Geosciences, vol. 66, pp. 106-120, 2014.

[59] L. Griffiths, M. J. Heap, P. Baud, and J. Schmittbuhl, "Quantification of microcrack characteristics and implications for stiffness and strength of granite," International Journal of Rock Mechanics and Mining Sciences, vol. 100, pp. 138-150, 2017.

[60] J. T. Fredrich and T. F. Wong, "Micromechanics of thermally induced cracking in three crustal rocks," Journal of Geophysical Research, vol. 91, no. 12, pp. 12743-12764, 1986.

[61] M. Paterson and T.-F. Wong, Experimental Rock Deformation, the Brittle Field, Springer, vol. 143, pp. 934-936, 2nd edition, 2005.

[62] S. Vinciguerra, C. Trovato, P. G. Meredith, and P. M. Benson, "Relating seismic velocities, thermal cracking and permeability in Mt. Etna and Iceland basalts," International Journal 
of Rock Mechanics and Mining Sciences, vol. 42, no. 7-8, pp. 900-910, 2005.

[63] M. Darot, Y. Guéguen, and M.-L. Baratin, "Permeability of thermally cracked granite," Geophysical Research Letters, vol. 19, no. 9, pp. 869-872, 1992.

[64] H. C. Heard and L. Page, "Elastic moduli, thermal expansion, and inferred permeability of two granites to $350^{\circ} \mathrm{C}$ and 55 megapascals," Journal of Geophysical Research, vol. 87, no. 11, pp. 9340-9348, 1982.

[65] L. Griffiths, M. J. Heap, T. Xu, C.-F. Chen, and P. Baud, "The influence of pore geometry and orientation on the strength and stiffness of porous rock," Journal of Structural Geology, vol. 96, pp. 149-160, 2017.

[66] A. Bubeck, R. J. Walker, D. Healy, M. Dobbs, and D. A. Holwell, "Pore geometry as a control on rock strength," Earth and Planetary Science Letters, vol. 457, pp. 38-48, 2017.

[67] J. Fortin, Y. Guéguen, and A. Schubnel, "Effect of pore collapse and grain crushing on ultrasonic velocities and $V_{p} /$ $V_{s}$," Journal of Geophysical Research, vol. 112, pp. 1-16, 2007.

[68] Complete publications details not given in the reference list, Query raised.

[69] R.-R. Zhang, J. Lai-Wang, and Q.-Y. Ma, "Experimental study on thermal damage and energy evolution of sandstone after high temperature treatment," Shock and Vibration, vol. 2018, Article ID 3845353, 9 pages, 2018.

[70] M. Lion, "Influence of temperature on the poromechanical or hydraulic behavior of a carbonate rock and a mortar," $\mathrm{Ph}$. D. Thesis, p. 192, University of Sciences and Technology, Lille, France, 2004.

[71] Y.-J. Shen, Y.-L. Zhang, F. Gao, G.-S. Yang, and X.-P. Lai, "Influence of temperature on the microstructure deterioration of sandstone," Energies, vol. 11, no. 7, p. 1753, 2018.

[72] M. J. Heap, F. B. Wadsworth, T. Xu, C.-F. Chen, and C. A. Tang, "The strength of heterogeneous volcanic rocks: a 2D approximation," Journal of Volcanology and Geothermal Research, vol. 319, pp. 1-11, 2016.

[73] S.-Q. Yang, P. Xu, Y.-B. Li, and Y.-H. Huang, "Experimental investigation on triaxial mechanical and permeability behavior of sandstone after exposure to different high temperature treatments," Geothermics, vol. 69, pp. 93-109, 2017.

[74] X.-Q. Wang, A. Schubnel, J. Fortin, Y. Guéguen, and H.-K. Ge, "Physical properties and brittle strength of thermally cracked granite under confinement," Journal of Geophysical Research: Solid Earth, vol. 118, no. 12, pp. 6099-6112, 2013.

[75] S. Chaki, M. Takarli, and W. P. Agbodjan, "Influence of thermal damage on physical properties of a granite rock: porosity, permeability and ultrasonic wave evolutions," Construction and Building Materials, vol. 22, no. 7, pp. 1456-1461, 2008.

[76] N. L. L. Mambou, J. Ndop, and J.-M. Ndjaka, "Investigations of thermal damage on the physical and mechanical properties of gneiss rock specimen," Journal of Powder Metallurgy and Mining, vol. 6, no. 176, pp. 1-6, 2017.

[77] J. Farquharson, M. J. Heap, N. R. Varley, P. Baud, and T. Reuschlé, "Permeability and porosity relationships of edifice-forming andesites: a combined field and laboratory study," Journal of Volcanology and Geothermal Research, vol. 297, pp. 52-68, 2015.

[78] J. I. Farquharson, M. J. Heap, and P. Baud, "Strain-induced permeability increase in volcanic rock," Geophysical Research Letters, vol. 43, no. 22, pp. 1-12, 2016.

[79] P. Baud, U. Exner, M. Lommatzsch, T. Reuschlé, and T.-F. Wong, "Mechanical behavior, failure mode, and transport properties in a porous carbonate," Journal of Geophysical Research: Solid Earth, vol. 122, no. 9, pp. 7363-7387, 2017.

[80] P. Baud, A. Schubnel, M. Heap, and A. Rolland, "inelastic compaction in high-porosity limestone monitored using acoustic emissions," Journal of Geophysical Research: Solid Earth, vol. 122, no. 12, pp. 9989-10008, 2017.

[81] L. He, Q. Yin, and H. Jing, "Laboratory investigation of granite permeability after high-temperature exposure," Processes, vol. 6, no. 4, pp. 36-14, 2018.

[82] Q. Sun, W. Zhang, Y. Zhang, and L. Yang, "Variations of strength, resistivity and thermal parameters of clay after high temperature treatment," Acta Geophysica, vol. 64, no. 6, p. 2077, 2016.

[83] X.-L. Xu, F. Gao, X.-M. Shen, and H.-P. Xie, "Mechanical characteristics and microcosmic mechanisms of granite under temperature loads," Journal of China University of Mining and Technology, vol. 18, pp. 413-417, 2008.

[84] H. Tian, T. Kempka, S. Yu, and M. Ziegler, "Mechanical properties of sandstones exposed to high temperature," Rock Mechanics and Rock Engineering, vol. 49, no. 1, pp. 321-327, 2016.

[85] M. Takada, Y. Fujii, and K. Jun-lchi, "Study on the effect of confining pressure on permeability of rock in triaxial compression failure process," Journal of MMIJ, vol. 127, pp. 151-157, 2012.

[86] Y.-L. Chen, S.-R. Wang, J. Ni, R. Azzam, and T. M. Fernández-steeger, "An experimental study of the mechanical properties of granite after high temperature exposure based on mineral characteristics," Engineering Geology, vol. 220, pp. 234-242, 2017.

[87] X.-Q. Wang, A. Schubnel, J. Fortin, E. C. David, Y. Guéguen, and H.-K. Ge, "High $V_{p} / V_{s}$ ratio: saturated cracks or anisotropy effects?" Geophysical Research Letters, vol. 39, no. 11, p. 11307, 2012.

[88] R. Houpert and E. Homand, "Influence of temperature on the mechanical behavior of rocks," in Proceedings of 4 th International Congress of Rock Mechanics, pp. 115-122, Rotterdam, Netherlands, September 1979.

[89] H. Tian, T. Kempka, N.-X. Xu, and M. Ziegler, "Physical properties of sandstones after high temperature treatment," Rock Mechanics and Rock Engineering, vol. 45, no. 6, pp. 1113-1117, 2012.

[90] Zulfahmi, S. Ildrem, Abdurrokhim, and R. K. Wattimena, "Thermal effects of geomechanics characteristics of soft rocks from M. Enim formation," in Proceedings of the 2017 World Congress on Advances in structural Engineering and mechanics, vol. 17, pp. 1-19, Seoul, Korea, August 2017.

[91] M. Yao, G. Rong, C. Zhou, and J. Peng, "Effects of thermal damage and confining pressure on the mechanical properties of coarse marble," Rock Mechanics and Rock Engineering, vol. 49, no. 6, pp. 2043-2054, 2016.

[92] J. Zhang, X. Chen, and H. Kang, "Experimental investigation of mechanical properties and energy features of granite after heat treatment under different loading paths," Technical Gazette, vol. 24, no. 6, pp. 1641-1851, 2017.

[93] A. Kožušníková, P. Konecnya, E. Plevova, and L. Králová, "Changes of physical properties of silesian granite due to heat loading," Procedia Engineering, vol. 191, pp. 426-433, 2017.

[94] N. L. L. Mambou, J. Ndop, and J.-M. Ndjaka, "Modeling and numerical analysis of granite rock specimen under mechanical loading and fire," Journal of Rock Mechanics and Geotechnical Engineering, vol. 7, pp. 105-108, 2014. 
[95] Y.-L. Chen, J. Ni, W. Shao, and R. Azzam, "Experimental study on the influence of temperature on the mechanical properties of granite under uni-axial compression and fatigue loading," International Journal of Rock Mechanics and Mining Sciences, vol. 56, pp. 62-66, 2012.

[96] S. Shao, P. G. Ranjith, P. L. P. Wasantha, and B. K. Chen, "Experimental and numerical studies on the mechanical behaviour of Australian Strathbogie granite at high temperatures: an application to geothermal energy," Geothermics, vol. 54, pp. 96-108, 2015.

[97] B. Kong, W. Enyuan, Z. Li et al., "Electromagnetic radiation characteristics and mechanical properties of deformed and fractured sandstone after high temperature treatment," Engineering Geology, vol. 209, pp. 82-92, 2016.

[98] B. Budiansky and R. J. O'connell, "Elastic moduli of a cracked solid," International Journal of Solids and Structures, vol. 12, no. 2, pp. 81-97, 1976.

[99] A. Török and Á. Török, "The effect of temperature on the strength of two different granites," Central European Geology, vol. 58, no. 4, pp. 356-369, 2016.

[100] Z. L. Wang, H. Shi, and J. G. Wang, "Mechanical behavior and damage constitutive model of granite under coupling of temperature and dynamic loading," Rock Mechanics and Rock Engineering, vol. 51, no. 10, pp. 3045-3059, 2018.

[101] W. Korzeniowski and K. Skrzypkowski, "Investigations of changes of selected geo-mechanical properties of rocks under the influence of temperature up to $1100^{\circ} \mathrm{C}$ in the aspect of potential underground coal gasification process," Przeglad Gorniczy, vol. 68, pp. 44-53, 2012.

[102] L. Zhang, X. Mao, L. Ruixue, G. Xiaoqian, and M. Dan, "The mechanical properties of mudstone at high temperatures: an experimental study," Rock Mechanics and Rock Engineering, vol. 47, pp. 1479-1484, 2013.

[103] J. Peng and S.-Q. Yang, "Comparison of mechanical behavior and acoustic emission characteristic of three thermallydamage rocks," Energies, vol. 11, no. 9, pp. 1-17, 2018.

[104] A. Sygała, M. Bukowska, and T. Janoszek, "High temperature versus geomechanical parameters of selected rocks-the present state of research," Journal of Sustainable Mining, vol. 12, no. 4, pp. 45-51, 2014.

[105] C. David, B. Menéndez, and M. Darot, "Influence of stressinduced and thermal cracking on physical properties and microstructure of La Peyratte granite," International Journal of Rock Mechanics and Mining Sciences, vol. 36, no. 4, pp. 433-448, 1999.

[106] B. Mahanta, N. Sirdesai, T. N. Singh, and P. G. Ranjith, "Experimental study of strain rate sensitivity to fracture toughness of rock using flattened Brazilian disc," Procedia Engineering, vol. 191, pp. 256-262, 2017.

[107] M. Hosseini and A. R. Khodayari, "Effects of temperature and confining pressure on mode II fracture toughness of rocks (case study: lushan sandstone)," Journal of Mining and Environment, vol. 9, no. 2, pp. 379-391, 2018.

[108] D.-M. Zhang, Y.-S. Yang, H. Yang, S. Yang, and Y. P. Chu, "Experimental study on the effect of high temperature on the mechanical properties and acoustic emission characteristics of gritstone," Results in Physics, vol. 9, pp. 1609-1617, 2018.

[109] R. W. Zimmerman, "The effect of microcracks on the elastic moduli of brittle materials," Journal of Materials Science Letters, vol. 4, no. 12, pp. 1457-1460, 1985.

[110] N. Brantut, M. Baker, L. N. Hansen, and P. Baud, "Microstructural control of physical properties during deformation of porous limestone," Journal of Geophysical Research: Solid Earth, vol. 123, no. 6, pp. 4751-4764, 2018.
[111] L. Shi and X. Jinyu, "An experimental study on the physicomechanical properties of two post-high-temperature rocks," Engineering Geology, vol. 185, pp. 63-70, 2014.

[112] H. Ersoy, H. Kolayli, M. Karahan, H. H. Karahan, and O. M. Sunnetci, "Effect of thermal damage on mineralogical and strength properties of basic volcanic rocks exposed to high temperatures," Bulletin of Engineering Geology and the Environment, vol. 78, no. 8, pp. 1-11, 2017.

[113] H. Su, H. Jing, Q. Yin, and Y. Liyuan, "Effect of thermal environment on the mechanical behaviors of building marble," Advances in Civil Engineering, vol. 2018, Article ID 1326503, 8 pages, 2018.

[114] X. L. Xu, M. Karakus, F. Gao, and Z.-Z. Zhang, "Thermal damage constitutive model for rock considering damage threshold and residual strength," Journal of Central South University, vol. 25, no. 10, pp. 2523-2536, 2018.

[115] X. L. Xu and Z.-Z. Zhang, "Acoustic emission and damage characteristics of granite subjected to high temperature," Advances in Materials Science and Engineering, vol. 2018, Article ID 8149870, 12 pages, 2018.

[116] W. Yu, L. Bao-Lin, Z. Hai-Yan, Y. Chuan-Liang, L. Zhi-Jun, and W. Zhi-Qiao, "Thermophysical and mechanical properties of granite and its effects on borehole stability in high temperature and three-dimensional stress," The Scientific World Journal, vol. 2014, Article ID 650683, 11 pages, 2014.

[117] S. Sha, G. Rong, J. Tan, R. He, and B. Li, "Tensile strength and brittleness of sandstone and granite after high-temperature treatment: a review," Arabian Journal of Geosciences, vol. 13, p. 598, 2020.

[118] W. Liu, Z. Dan, Y. Jia, and X. Zhu, "On the statistical damage constitutive model and damage evolution of hard rock at high-temperature," Geotechnical and Geological Engineering, vol. 38, pp. 4307-4318, 2020.

[119] N. L. L. Mambou, J. Ndop, and J. M. B. Ndjaka, "Theoretical investigations of mechanical properties of sandstone rock specimen at high temperatures," Journal of Mining Science, vol. 50, no. 1, pp. 69-80, 2015.

[120] S.-Q. Yang, W.-L. Tian, and Y.-H. Huang, "Failure mechanical behavior of pre-holed granite specimens after elevated temperature treatment by particle flow code," Geothermics, vol. 72, pp. 124-137, 2018.

[121] S.-Q. Yang, W.-L. Tian, and P. G. Ranjith, "Failure mechanical behavior of Australian Strathbogie granite at high temperatures: insights from particle flow modeling," Energies, vol. 10, no. 6, pp. 756-19, 2017.

[122] W. M. Foguieng, N. L. L. Mambou, and F. Ngapgue, "Modeling and numerical analysis in 3D of anisotropic and nonlinear mechanical behavior of tournemire argillite under high temperatures and dynamic loading," The Scientific World Journal, vol. 2020, Article ID 2978257, 20 pages, 2020.

[123] Y. Liyuan, S. Haijian, L. Richeng, J. Hongwen, L. Guanglei, and M. Li, "Effect of thermal treatment on the dynamic behaviors at a fixed loading rate of limestone in quasivacuum and air-filled environments," Latin American Journal of Solids and Structures, vol. 15, no. 3, pp. 1-20, 2018. 